\title{
Ion Pairs of Weakly Coordinating Cations and Anions: Synthesis and Application for Sulfide to Sulfoxide Oxidations
}

\author{
Bo Zhang ${ }^{\mathrm{a}}$, Su Li ${ }^{\mathrm{a}}$, Mirza Cokoja ${ }^{\mathrm{a}}$, Eberhardt Herdtweck ${ }^{\mathrm{a}}$, János Mink ${ }^{\mathrm{b}}$, \\ Shu-Liang Zang ${ }^{c}$, Wolfgang A. Herrmann ${ }^{\mathrm{a}}$, and Fritz E. Kühn ${ }^{\mathrm{a}}$ \\ a Chair of Inorganic Chemistry/Molecular Catalysis, Catalysis Research Center, Technische \\ Universität München, Ernst-Otto-Fischer-Straße 1, D-85747 Garching bei München, Germany \\ b Institute of Molecular Pharmacology, Research Centre for Natural Sciences, Hungarian \\ Academy of Sciences, Budapest, H-1525 Hungary; Faculty of Information Technology, \\ University of Pannonia, Research Institute of Chemical and Process Engineering, Veszprém, \\ H-8201, Hungary \\ c Department of Petroleum and Chemical Technology, Liaoning University of Petroleum and \\ Chemical Technology, Dandong Road, No. 1, 113001 Fushun, P. R. China; Institute of Rare \\ and Scattered Elements Chemistry, Liaoning University, Chongshan Middle Road No. 66, \\ 110036 Shenyang, P. R. China
}

Reprint requests to Prof. Dr. F. E. Kühn. Tel: +49 89289 13096. Fax: +49 8928913473.

E-mail: fritz.kuehn@ch.tum.de

Z. Naturforsch. 2014, 69b, 1149-1163 / DOI: 10.5560/ZNB.2014-4165

Received July 31, 2014

Dedicated to Professor Hubert Schmidbaur on the occasion of his $80^{\text {th }}$ birthday

A series of salts containing the weakly coordinating cations (WCC) 1-butyl-3-methylimidazolium $\left([\mathrm{Bmim}]^{+}\right)$1-butyl-2,3-dimethylimidazolium $\left([\mathrm{Bdmim}]^{+}\right)$, 1-dodecyl-3-methylimidazolium $\left(\left[\mathrm{C}_{12} \mathrm{mim}\right]^{+}\right)$, tetrabutylphosphonium $\left(\left[\mathrm{PBu}_{4}\right]^{+}\right)$, tributyltetradecylphosphonium $\left(\left[\mathrm{P}_{4,4.4,14}\right]^{+}\right)$, tetrabutylammonium $\left(\left[\mathrm{NBu}_{4}\right]^{+}\right)$, and 1,1,3,3-tetramethylguanidium $\left([\mathrm{TMG}]^{+}\right.$) and fluorinated tetraarylborate anions of the type $\left[\mathrm{B}\left(\mathrm{Ar}^{\mathrm{F}}\right)_{4}\right]\left(\mathrm{Ar}^{\mathrm{F}}=\mathrm{C}_{6} \mathrm{~F}_{5}, \mathrm{C}_{6} \mathrm{H}_{3}-3,5-\left(\mathrm{CF}_{3}\right)_{2}\right)$ were synthesized and characterized. The influence of cations and anions on the physical properties of the obtained compounds was examined. In case of the compound $[\mathrm{TMG}]\left[\mathrm{B}\left(\mathrm{C}_{6} \mathrm{~F}_{5}\right)_{4}\right]$ hydrogen-fluorine contacts between cation and anion are present in the solid state. Owing to $\mathrm{H} \cdots \mathrm{F}$ contacts between hydrogen peroxide and the fluorine substituents of the anion and the resulting activation of $\mathrm{H}_{2} \mathrm{O}_{2}$ in solution, the compound $\left[\mathrm{P}_{4,4,4,14}\right]\left[\mathrm{B}\left(\mathrm{C}_{6} \mathrm{H}_{3}-3,5-\left(\mathrm{CF}_{3}\right)_{2}\right)_{4}\right]$ is applicable as an efficient mediator for the oxidation of sulfides to sulfoxides.

Key words: Weakly Coordinating Anion, Hydrogen Peroxide, Oxidation, Sulfide, Sulfoxide

\section{Introduction}

The growing importance of environmental issues for society and industry during the past few decades has led to increasing attention to the need for more environmentally friendly and more sustainable technologies in chemical industry $[1-8]$. Minding this background, ionic liquids (IL) have been regarded as promising reaction media, as they are often non-toxic and not volatile. Yet, most importantly, they can be tailor-made to achieve desired properties, e.g. high hydrophobicity and concomitant high polarity, thus offering a large variety of compounds with different cations and anions [9-17]. It is therefore not surprising that ILs play an important role in recent examinations aiming at "green" chemistry and applications in catalysis [3, 4, 7, 9, 18-23] The degree of ion pairing interactions and the size and charge distribution of the ions influence the melting point, viscosity and conductivity [20, 24, 25]. The ion pairing interactions can be ascribed to the strength of different bonding types between the ions, mainly Coulomb forces and hydrogen contacts, which depend on the Lewis basicity of the anions [26-34]. For this reason, ion pairs containing weakly coordinating cations (WCC; e.g. ammonium, phosphonium, pyri- 
dinium, imidazolium) and weakly coordinating anions (WCA; e.g. $\left[\mathrm{BF}_{4}\right]^{-},\left[\mathrm{PF}_{6}\right]^{-},\left[\mathrm{AlCl}_{4}\right]^{-},\left[\mathrm{CF}_{3} \mathrm{SO}_{3}\right]^{-}$, $\left.\left[\mathrm{N}\left\{\mathrm{SO}_{2}\left(\mathrm{CF}_{3}\right)\right\}_{2}\right]^{-}\right)$are among the best studied IL systems $[35,36]$, as they exhibit weak Coulomb (owing to charge delocalization) and weak hydrogen bonding interactions [1-3]. For example, ILs consisting of $\left[\mathrm{Al}\left(\mathrm{OR}^{\mathrm{F}}\right)_{4}\right]^{-}\left(\mathrm{R}^{\mathrm{F}}=\mathrm{C}\left(\mathrm{CF}_{3}\right)_{3}, \mathrm{C}(\mathrm{H})\left(\mathrm{CF}_{3}\right)_{2}\right.$, $\left.\mathrm{C}\left(\mathrm{CH}_{3}\right)\left(\mathrm{CF}_{3}\right)_{2}, \mathrm{C}(\mathrm{Ph})\left(\mathrm{CF}_{3}\right)_{2}\right)$ anions associated with imidazolium cations have been described and applied as solvents for electrochemical and catalytic applications [37-40]. Matsumoto et al. prepared and characterized low-melting and low-viscous ILs with perfluoroalkyltrifluoroborates [41-44]. A comprehensive examination of ionic compounds based on carborane [45-47] or azolate [48, 49] anions was also performed. However, in terms of anion stability, it has been shown that weakly coordinating fluorinated tetraarylborate $\left[\mathrm{B}\left(\mathrm{Ar}^{\mathrm{F}}\right)_{4}\right]^{-}$anions $\left(\mathrm{Ar}^{\mathrm{F}}=\mathrm{C}_{6} \mathrm{~F}_{5}\right.$, $\left.-\mathrm{C}_{6} \mathrm{H}_{3}-3,5-\left(\mathrm{CF}_{3}\right)_{2}\right)$ are much more stable than the above mentioned anions [50-54]. Therefore, $\left[\mathrm{B}\left(\mathrm{Ar}^{\mathrm{F}}\right)_{4}\right]^{-}$anions are widely used as counterions for a plethora of cationic catalysts, e.g. for the polymerization of olefins [55-58].

Recently it has been demonstrated that a reduced ion pairing interaction leads to an increased nucleophilicity of perrhenate $[59,60]$ and polyoxomolybdate [61, 62] anions, rendering anion-based activation of $\mathrm{H}_{2} \mathrm{O}_{2}$ and oxidation of olefins and sulfides possible. Additionally, the synthesis of imidazolium salts containing the $\left[\mathrm{B}\left(\mathrm{C}_{6} \mathrm{~F}_{5}\right)_{4}\right]^{-}$anion showing a weak cation-anion interaction was reported [63]. The tetrafluoroborate anion is also capable of activating hydrogen peroxide by forming hydrogen bonds, which leads to the oxidation of sulfides [65]. These findings led to the idea of synthesizing several different ionic compounds with weakly coordinating cations and fluoride-containing weakly coordinating anions (WCCWCA), and investigating the relationship between the structure and the resulting physical properties. In this work a series of WCCWCAs, prepared by combining the organic cations (1-butyl-3-methylimidazolium $\left([\mathrm{Bmim}]^{+}\right)$, 1-butyl2,3-dimethylimidazolium $\left([\mathrm{Bdmim}]^{+}\right)$, 1-dodecyl3-methylimidazolium $\left(\left[\mathrm{C}_{12} \mathrm{mim}\right]^{+}\right)$, tetrabutylphosphonium $\left(\left[\mathrm{PBu}_{4}\right]^{+}\right)$, tributyltetradecylphosphonium $\left(\left[\mathrm{P}_{4,4,4,14}\right]^{+}\right)$, tetrabutylammonium $\left(\left[\mathrm{NBu}_{4}\right]^{+}\right)$, and 1,1,3,3-tetramethylguanidium $\left(\left[\mathrm{TMG}^{+}\right)\right.$) with two different $\left[\mathrm{B}\left(\mathrm{Ar}^{\mathrm{F}}\right)_{4}\right]^{-}$anions $\left(\mathrm{Ar} \mathrm{F}^{\mathrm{F}}=\mathrm{C}_{6} \mathrm{~F}_{5}, \quad-\mathrm{C}_{6} \mathrm{H}_{3}-\right.$ $\left.3,5-\left(\mathrm{CF}_{3}\right)_{2}\right)$ is described. In analogy to our previous studies $[62,64]$, some of the new WCCWCAs were applied as mediators for the oxidation of sulfides to sulfoxides. Oxidation of sulfur-containing compounds is of considerable current interest for industrial chemistry and petrochemistry [65-69].

\section{Results and Discussion}

\section{Synthesis and characterization}

The WCCWCAs were synthesized according to modified literature procedures [64]. They can be accessed via salt metathesis from WCC-halide salts and either lithium- or silver-WCAs, as shown in Scheme 1. $\mathrm{Li}\left[\mathrm{B}\left(\mathrm{C}_{6} \mathrm{~F}_{5}\right)_{4}\right]$ and $\mathrm{Li}\left[\mathrm{B}\left\{\mathrm{C}_{6} \mathrm{H}_{3}-3,5-\left(\mathrm{CF}_{3}\right)_{2}\right\}_{4}\right]$ were synthesized according to literature procedures [64, 70]. WCCWCAs $\mathbf{1 a - 7 a}$ and $\mathbf{1 b}-\mathbf{7 b}$ are obtained by the reaction of $\mathrm{Li}\left[\mathrm{B}\left(\mathrm{C}_{6} \mathrm{~F}_{5}\right)_{4}\right]$ or $\mathrm{Li}\left[\mathrm{B}\left\{\mathrm{C}_{6} \mathrm{H}_{3}-3,5-\left(\mathrm{CF}_{3}\right)_{2}\right\}_{4}\right]$ with WCC halides in dry $\mathrm{CH}_{2} \mathrm{Cl}_{2}$ under argon atmosphere with a reaction time of $2 \mathrm{~h}$ at room temperature. After precipitation of the by-product and filtration of the product-containing supernatant, the solvent is removed under vacuum. The remaining product is washed with dry pentane, and dried under high vacuum for one day. The yields of the purified products are $55-62 \%$. In order to increase the yield and reduce the reaction time, $\operatorname{Ag}\left[\mathrm{B}\left(\mathrm{C}_{6} \mathrm{~F}_{5}\right)_{4}\right]$ and $\mathrm{Ag}\left[\mathrm{B}\left\{\mathrm{C}_{6} \mathrm{H}_{3}\right.\right.$ $\left.\left.3,5-\left(\mathrm{CF}_{3}\right)_{2}\right\}_{4}\right]$ have been selected as precursors for the synthesis of the WCCWCAs. $\operatorname{Ag}\left[\mathrm{B}\left(\mathrm{C}_{6} \mathrm{~F}_{5}\right)_{4}\right]$ and $\mathrm{Ag}\left[\mathrm{B}\left\{\mathrm{C}_{6} \mathrm{H}_{3}-3,5-\left(\mathrm{CF}_{3}\right)_{2}\right\}_{4}\right]$ were prepared according to literature procedures [71]

The reaction is carried out under exclusion of light at room temperature in dry $\mathrm{CH}_{2} \mathrm{Cl}_{2}$. The reaction mixture is stirred for $10 \mathrm{~min}$, while the by-product precipitates. After filtration, the solvent is removed under high vacuum to obtain the raw product. This raw product is then washed with dry pentane and dried under vacuum for one day. Typical yields of the pure products are $85-95 \%$. Hence, the best results are usually obtained with silver salts rather than lithium salts in dry dichloromethane. All prepared WCCWCAs are stable to air and moisture. All synthesized compounds are solid at room temperature, with the exception of $\mathbf{6 a}$, which is a pale-yellow liquid with a melting point of $-39^{\circ} \mathrm{C}$ (see Table 1). All salts display high solubility in water and polar organic solvents such as $\mathrm{CH}_{2} \mathrm{Cl}_{2}$, $\mathrm{CH}_{3} \mathrm{CN}$ and alcohols, but low solubility in $n$-hexane.

The WCCWCAs 1a-7a and $\mathbf{1 b}-\mathbf{7 b}$ have been characterized by FT-IR, NMR spectroscopy and elemental analysis (see the Experimental Section). Melting 


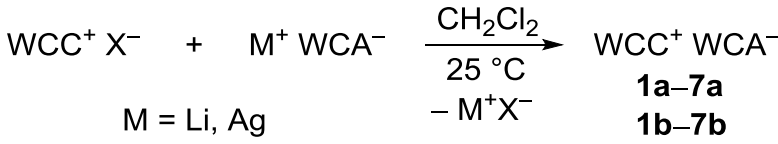

$$
\begin{aligned}
& \mathrm{X}=\mathrm{Cl}, \mathrm{Br}
\end{aligned}
$$<smiles></smiles><smiles>CCN(C)C(C)(C)CC</smiles>

4<smiles>CC(C)(C)[B]Cc1c(F)c(F)c(C(C)(C)C)c(F)c1F</smiles>

a<smiles></smiles>

2<smiles></smiles>

5

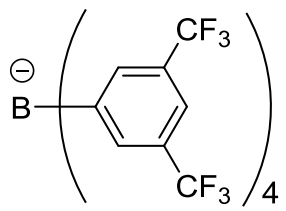

b<smiles></smiles>

3

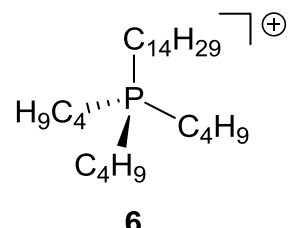<smiles>CN(C)C(=[NH2+])N(C)C</smiles>

7

Scheme 1. Synthesis of WCCWCA compounds $\mathbf{1 a}-\mathbf{7 a}$ and $\mathbf{1 b}-\mathbf{7 b}$.

points $\left(T_{\mathrm{m}}\right)$ were determined by differential scanning calorimetry (DSC). The results are summarized in Table 1. Note that the melting points of WCCWCAs with the $\left[\mathrm{B}\left\{\mathrm{C}_{6} \mathrm{H}_{3}-3,5-\left(\mathrm{CF}_{3}\right)_{2}\right\}_{4}\right]$ anion $(\mathbf{1 b}-\mathbf{7 b})$ are significantly lower than those with the $\left[\mathrm{B}\left(\mathrm{C}_{6} \mathrm{~F}_{5}\right)_{4}\right]^{-}$anion $(\mathbf{1 a}-\mathbf{7 a})$, indicating that the size of the anion affects the ion pairing and hence the long-range order [72]. The nature of the cation, however, also influences the melting point, as shown with the $\left[\mathrm{P}_{4,4,4,14}\right]^{+}$cation, which is giving rise to the long tetradecyl chain and hence, the lowest melting points in the series of the synthesized WCCWCAs, being $-39^{\circ} \mathrm{C}$ for $6 \mathbf{a}$ and $49^{\circ} \mathrm{C}$ for $\mathbf{6 b}$. In contrast, WCCWCAs with cations of high $T_{\mathrm{d}}$ symmetry $(\mathbf{4}$ and $\mathbf{5})$ lead to higher melting points. It is reported that symmetry breaking in cations leads to lower melting points of ionic liquids [73]. Similarly, the melting points of $\mathbf{2 a}$ and $\mathbf{2} \mathbf{b}$ decrease with increasing length of the alkyl chain from butyl to dodecyl due to increasing cation size and decreasing cation symmetry. Generally, WCCWCAs with cations exhibiting acidic protons (imidazolium, guanidinium) have higher melting points than those with ammonium and phosphonium cations, owing to hydrogen bonding between cation and anion, which is known to have an influence on the melting point (see also the crystal structures below) $[24-26,74-76]$.

The thermal stability of compounds $1 \mathbf{1 a}-\mathbf{7 a}$ and 1b-7b was determined by thermogravimetric analyses (TGA), with isocratic heating at $10^{\circ} \mathrm{C} \mathrm{min}-1$ under an

Table 1. Decomposition temperatures $T_{\mathrm{d}}$ and melting points $T_{\mathrm{m}}$ of the synthesized WCCWCAs.

\begin{tabular}{lccc}
\hline Entry & Compound & $T_{\mathrm{d}}\left({ }^{\circ} \mathrm{C}\right)$ & $T_{\mathrm{m}}\left({ }^{\circ} \mathrm{C}\right)$ \\
\hline 1 & {$[\mathrm{Bmim}]\left[\mathrm{B}\left(\mathrm{C}_{6} \mathrm{~F}_{5}\right)_{4}\right](\mathbf{1 a})$} & 245 & 145 \\
2 & {$[\mathrm{Bdmim}]\left[\mathrm{B}\left(\mathrm{C}_{6} \mathrm{~F}_{5}\right)_{4}\right](\mathbf{2 a})$} & 270 & 151 \\
3 & {$\left[\mathrm{C}_{12} \mathrm{mim}\right]\left[\mathrm{B}\left(\mathrm{C}_{6} \mathrm{~F}_{5}\right)_{4}\right](\mathbf{3 a})$} & 287 & 120 \\
4 & {$\left[\mathrm{NBu}_{4}\right]\left[\mathrm{B}\left(\mathrm{C}_{6} \mathrm{~F}_{5}\right)_{4}\right](\mathbf{4 a})$} & 220 & 159 \\
5 & {$\left[\mathrm{PBu}_{4}\right]\left[\mathrm{B}\left(\mathrm{C}_{6} \mathrm{~F}_{5}\right)_{4}\right](\mathbf{5 a})$} & 330 & 114 \\
6 & {$\left[\mathrm{P}_{4}, 4,4,14\right]\left[\mathrm{B}\left(\mathrm{C}_{6} \mathrm{~F}_{5}\right)_{4}\right](\mathbf{6 a})$} & 337 & -39 \\
7 & {$[\mathrm{TMG})\left[\mathrm{B}\left(\mathrm{C}_{6} \mathrm{~F}_{5}\right)_{4}\right](\mathbf{7 a})$} & 255 & 152 \\
8 & {$[\mathrm{Bmim}]\left[\mathrm{B}\left\{\mathrm{C}_{6} \mathrm{H}_{3}-3,5-\left(\mathrm{CF}_{3}\right)_{2}\right\}_{4}\right](\mathbf{1 b})$} & 260 & 106 \\
9 & {$[\mathrm{Bdmim}]\left[\mathrm{B}\left\{\mathrm{C}_{6} \mathrm{H}_{3}-3,5-\left(\mathrm{CF}_{3}\right)_{2}\right\}_{4}\right](\mathbf{2 b})$} & 255 & 91 \\
10 & {$\left[\mathrm{C}_{12} \mathrm{mim}\right]\left[\mathrm{B}\left\{\mathrm{C}_{6} \mathrm{H}_{3}-3,5-\left(\mathrm{CF}_{3}\right)_{2}\right\}_{4}\right](\mathbf{3 b})$} & 284 & 73 \\
11 & {$\left[\mathrm{NBu}_{4}\right]\left[\mathrm{B}\left\{\mathrm{C}_{6} \mathrm{H}_{3}-3,5-\left(\mathrm{CF}_{3}\right)_{2}\right\}_{4}\right](\mathbf{4 b})$} & 238 & 92 \\
12 & {$\left[\mathrm{PBu}_{4}\right]\left[\mathrm{B}\left\{\mathrm{C}_{6} \mathrm{H}_{3}-3,5-\left(\mathrm{CF}_{3}\right)_{2}\right\}_{4}\right](\mathbf{5 b})$} & 300 & 121 \\
13 & {$\left[\mathrm{P}_{4,4,4,14}\right]\left[\mathrm{B}\left\{\mathrm{C}_{6} \mathrm{H}_{3}-3,5-\left(\mathrm{CF}_{3}\right)_{2}\right\}_{4}\right](\mathbf{6 b})$} & 318 & 49 \\
14 & {$\left[\mathrm{TMG}^{2}\right]\left[\mathrm{B}\left\{\mathrm{C}_{6} \mathrm{H}_{3}-3,5-\left(\mathrm{CF}_{3}\right)_{2}\right\}_{4}\right](\mathbf{7 b})$} & 250 & 156 \\
\hline
\end{tabular}

${ }^{a}$ Glass transition temperature. 
inert argon atmosphere. All WCCWCAs are thermally stable beyond $240^{\circ} \mathrm{C}$ (Table 1). The decomposition points also appear to mainly depend on the structure of the anion. With longer alkyl substituents at the cation, the decomposition temperature increases. Phosphonium WCCWCAs show higher thermal stability than the corresponding imidazolium salts. Previous reports have shown that salt compounds containing WCAs a and $\mathbf{b}$ and cationic transition metal complexes usually decompose below $200^{\circ} \mathrm{C}$ [77-79], indicating that the WCCWCAs display increased thermal stability.

\section{Crystal structure analysis}

Single crystals of $\mathbf{2 b}, \mathbf{5 a}, \mathbf{6} \mathbf{b}$, and $7 \mathbf{a}$ were obtained by slow diffusion of $n$-hexane into a dichloromethane solution of the compounds at $-10^{\circ} \mathrm{C}$. The diffraction measurements were carried out at low temperatures (between 100 and $200 \mathrm{~K}$ ) in order to minimize rotation of the $\mathrm{CF}_{3}$ groups and ensure the accuracy of the evaluation of intermolecular interactions involving $\mathrm{F}$ and $\mathrm{H}$ atoms.

Compound $\mathbf{2 b}$ crystallizes in the monoclinic space group $P 2_{1} / c$ with $Z=4$ (Fig. 1). Noteworthy, there are no significant cation-anion contacts, which is giving rise to the substitution of a hydrogen atom at the $\mathrm{C} 2$ ring position by a methyl group (c.f. $[\mathrm{Bmim}]\left[\mathrm{B}\left(\mathrm{C}_{6} \mathrm{~F}_{5}\right)_{4}\right]$ (1a) [64]. This is in good agreement to previous observations that hydrogen bonds become less pronounced when the $\mathrm{H}$ atoms on the imidazolium ring are replaced by alkyl groups [28].

Compound 5a crystallizes in the orthorhombic space group Pca2 $2_{1}$ with two molecules per unit cell. The asymmetric unit consists of two $\left[\mathrm{PBu}_{4}\right]^{+}$ions and two $\left[\mathrm{B}\left(\mathrm{C}_{6} \mathrm{~F}_{5}\right)_{4}\right]^{-}$ions (Fig. 2). Expectedly, the B-C bond lengths $(1.656(2)-1.664(2) \AA)$ are in a similar range as the $\mathrm{B}-\mathrm{C}$ bond lengths $(1.657(4)-1.681(4) \AA)$ of the similar structure $\left[\mathrm{NBu}_{4}\right]\left[\mathrm{B}\left(\mathrm{C}_{6} \mathrm{~F}_{5}\right)_{4}\right]$ described

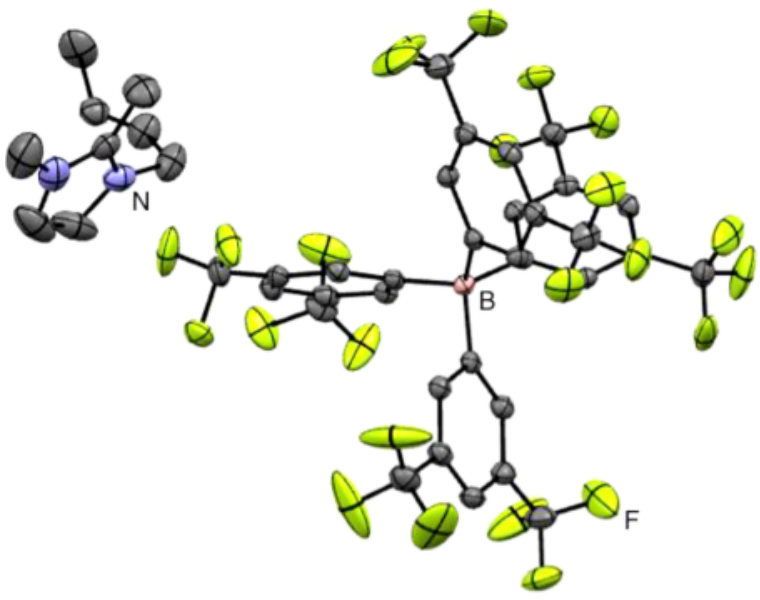

Fig. 1. (color online). ORTEP view of the solid-state structure of compound $\mathbf{2 b}$. Displacement ellipsoids are drawn at the $50 \%$ probability level. Hydrogen atoms are omitted for clarity. Atom colors: carbon: grey, nitrogen: blue, boron: pink, fluorine: green.

by M. Bolte $e t$ al. [80]. The bond lengths and angles are listed in Table 2. H.F.F contacts between the orthofluorine atoms and the $\gamma$ - and $\delta$-carbon atoms of the butyl substituents are visible.

Compound $\mathbf{6 b}$ crystallizes in the triclinic space group $P \overline{1}$ with $Z=2$. The structure is shown in Fig. 3 , and the crystallographic data are summarized in the Experimental Section. Interestingly, in comparison to compound 5a, there are significantly less $\mathrm{H} \cdots \mathrm{F}$ contacts in compound $\mathbf{6 b}$, which is most presumably a consequence of the steric repulsion of the tetradecyl group and the different basicities of fluorine atoms in $\mathrm{CF}_{3}$ and $\mathrm{C}_{6} \mathrm{~F}_{5}$ groups. The bond angle $(\mathrm{C}-\mathrm{B}-\mathrm{C})_{\text {min }}$ $\left(107.5(1)^{\circ}\right)$ is larger than that of other compounds containing the $\left[\mathrm{B}\left(\mathrm{C}_{6} \mathrm{~F}_{5}\right)_{4}\right]^{-}$anion, probably due to the steric hindrance of the longer carbon chain of the cation.

Table 2. Comparison of selected bond lengths $(\AA)$ and angles (deg).

\begin{tabular}{lccc}
\hline Entry & Compound & $\begin{array}{c}\text { Bond lengths }(\mathrm{B}-\mathrm{C}) \\
(\min -\mathrm{max})(\AA)\end{array}$ & $\begin{array}{c}\text { Bond angles }(\mathrm{C}-\mathrm{B}-\mathrm{C}) \\
(\mathrm{min}-\mathrm{max})(\mathrm{deg})\end{array}$ \\
\hline 1 & {$[\mathrm{Bmim}]\left[\mathrm{B}\left(\mathrm{C}_{6} \mathrm{~F}_{5}\right)_{4}\right](\mathbf{1 a})$} & $1.652(2)-1.655(2)[64]$ & $101.3(1)-114.6(1)[64]$ \\
2 & {$[\mathrm{Bdmim}]\left[\mathrm{B}\left(\mathrm{C}_{6} \mathrm{~F}_{5}\right)_{4}\right](\mathbf{2 a})$} & $1.653(3)-1.659(3)[64]$ & $101.2(1)-114.2(2)[64]$ \\
3 & {$\left[\mathrm{NBu}_{4}\right]\left[\mathrm{B}\left(\mathrm{C}_{6} \mathrm{~F}_{5}\right)_{4}\right](\mathbf{4 a})$} & $1.657(4)-1.681(14)[81]$ & $100.5(2)-115.5(2)[81]$ \\
4 & {$[\mathrm{PBu}, 4]\left[\mathrm{B}\left(\mathrm{C}_{6} \mathrm{~F}_{5}\right)_{4}\right](\mathbf{5 a})$} & $1.656(2)-1.664(2)$ & $101.4(1)-115.6(1)$ \\
5 & {$[\mathrm{TMG}]\left[\mathrm{B}\left(\mathrm{C}_{6} \mathrm{~F}_{5}\right)_{4}\right](\mathbf{7 a})$} & $1.39(2)-1.661(2)$ & $102.3(1)-113.3(1)$ \\
6 & {$[\mathrm{Dbmim}]\left[\mathrm{B}\left\{\mathrm{C}_{6} \mathrm{H}_{3}-3,5-\left(\mathrm{CF}_{3}\right)_{2}\right\}_{4}\right](\mathbf{2 b})$} & $1.635(2)-1.640(2)$ & $101.9(2)-122.7(1)$ \\
7 & {$\left[\mathrm{P}_{4,4,4,14}\right]\left[\mathrm{B}\left\{\mathrm{C}_{6} \mathrm{H}_{3}-3,5-\left(\mathrm{CF}_{3}\right)_{2}\right\}_{4}\right](\mathbf{6 b})$} & $1.649(2)-1.65(2)$ & $107.5(1)-111.1(1)$ \\
\hline
\end{tabular}




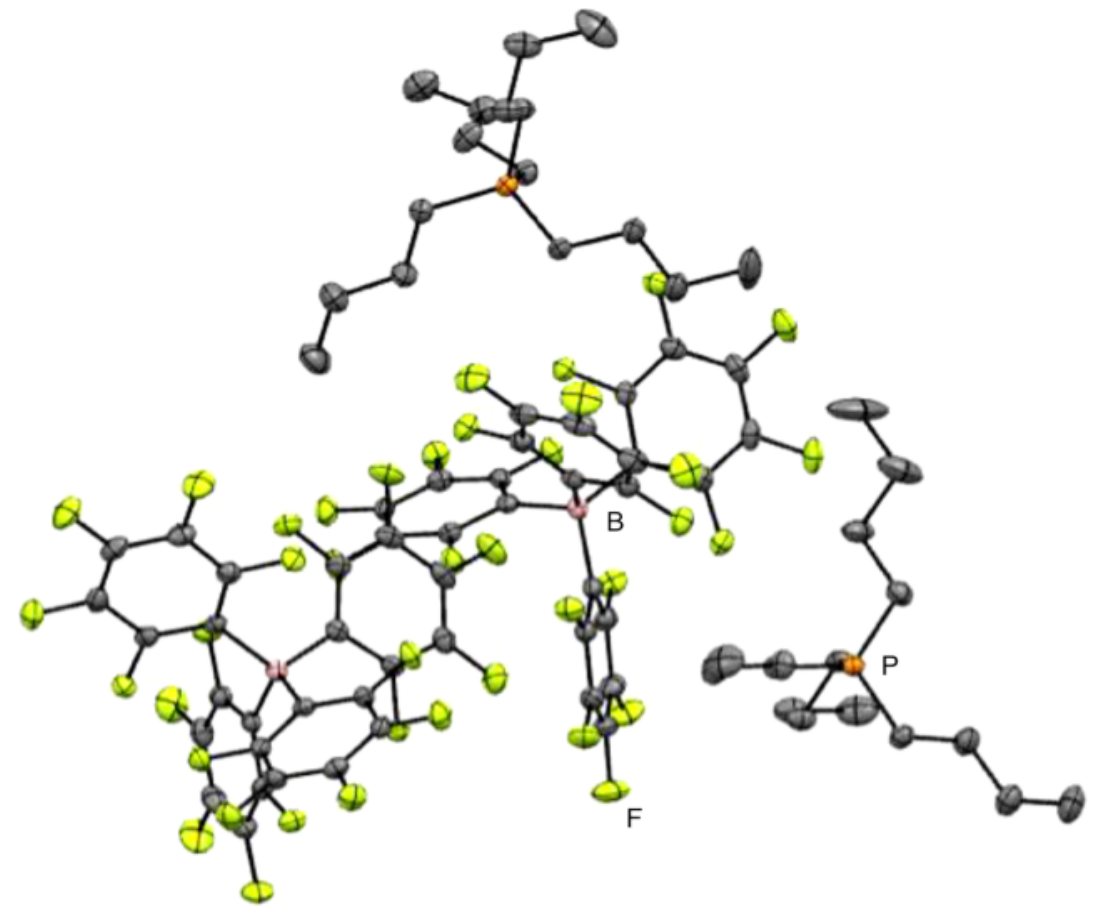

Fig. 2. (color online). ORTEP view of the solid-state structure of compound 5a. Displacement ellipsoids are drawn at the $50 \%$ probability level. Hydrogen atoms are omitted for clarity. Atom colors: carbon: grey, phosphorus: orange, boron: pink, fluorine: green.

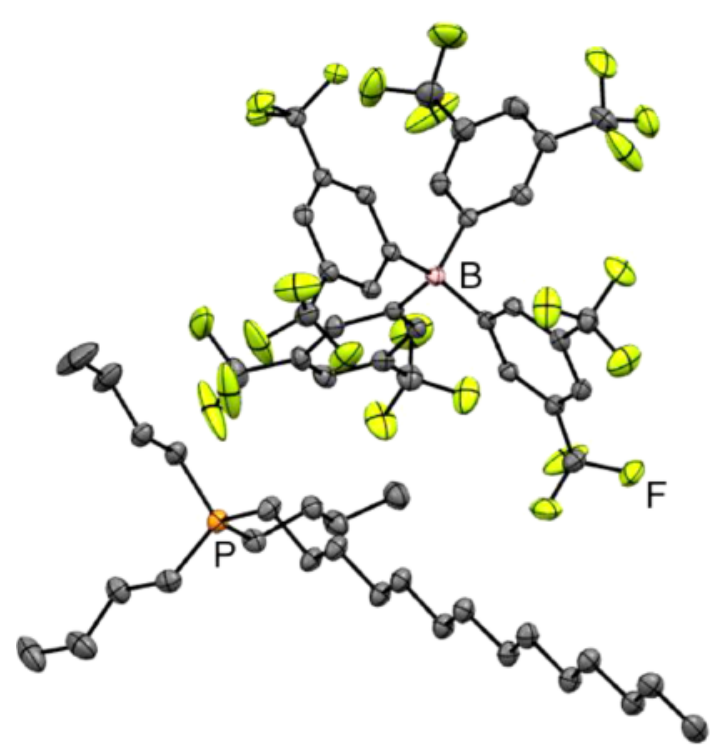

Fig. 3. (color online). ORTEP view of the solid-state structure of compound $\mathbf{6} \mathbf{b}$. Displacement ellipsoids are drawn at a $50 \%$ probability level. Hydrogen atoms are omitted for clarity. Atom colors: carbon: grey, phosphorus: orange, boron: pink, fluorine: green.

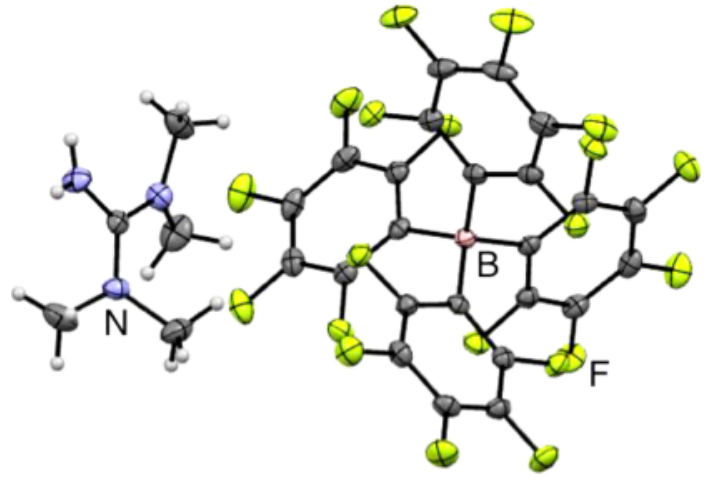

Fig. 4. (color online). ORTEP view of the solid-state structure of compound 7a. Displacement ellipsoids are drawn at a 50\% probability level. Atom colors: carbon: grey, nitrogen: blue, boron: pink, fluorine: green.

Compound 7a crystallizes in the triclinic space group $P \overline{1}$ with $Z=2$ (Fig. 4). It is noteworthy that hydrogen atoms could be located in the difference Fourier maps and are allowed to refine freely. In the solid state, compound 7a exhibits a plethora of 


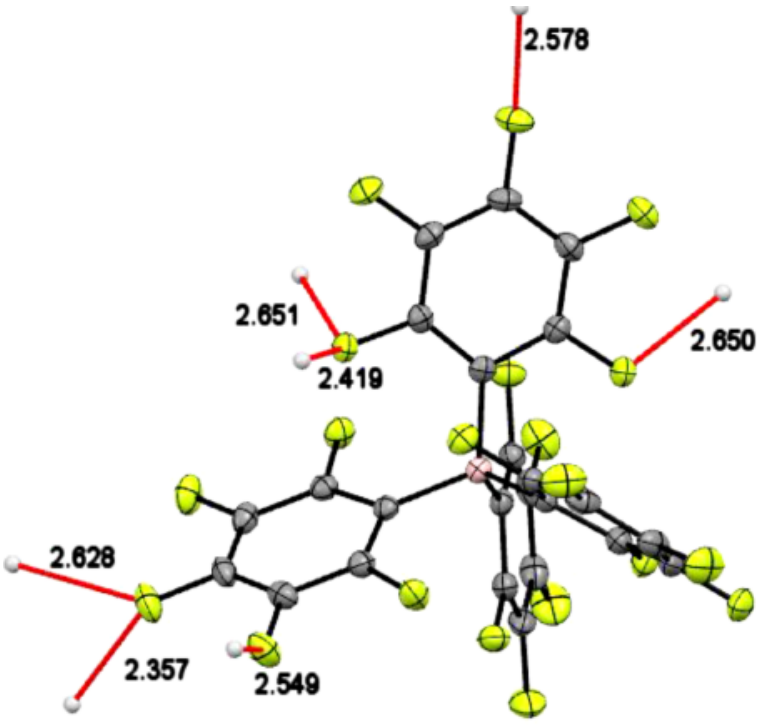

Fig. 5. (color online). Illustration of hydrogen contacts (in red color) of the fluoride groups of the $\left[\mathrm{B}\left(\mathrm{C}_{6} \mathrm{~F}_{5}\right)_{4}\right]^{-}$anion in $\mathbf{7 a}$.

hydrogen-bonding interactions between the $\mathrm{F}$ atoms of $\left[\mathrm{B}\left(\mathrm{C}_{6} \mathrm{~F}_{5}\right)_{4}\right]^{-}$and the hydrogen atoms of the 1,1,3,3tetramethylguanidinium (TMG) cation (Fig. 5). The length of the hydrogen bonds is in the range of 2.357 to $2.650 \AA$, respectively, which is in the range of typical $\mathrm{H} \cdots \mathrm{F}$ contacts $[81-85]$. The pronounced interactions between cation and anion via hydrogen bonds may be attributed to the relative acidity of the protons of the TMG cation.

\section{Oxidation of sulfides to sulfoxides mediated by WCCWCAs}

In analogy to the oxidation of sulfides to sulfoxides mediated by imidazolium tetrafluoroborates, the oxidation of sulfides to sulfoxides was carried out using compounds $\mathbf{6 a}$ and $\mathbf{6 b}$ as reaction media, since they exhibit the lowest melting points in the series of all synthesized WCCWCAs. Oxidation of thioanisole with aqueous $\mathrm{H}_{2} \mathrm{O}_{2}$ as the oxidant was found to be strongly solvent dependent (details concerning the reaction details are given in the Experimental Section). When using $\mathbf{6 a}$ as solvent, the sulfoxide yield is only $18 \%$ within $4 \mathrm{~h}$ with a selectivity of $90 \%$. In an analogous experiment using $6 \mathbf{b}$ nearly quantitative conversion and selectivity were obtained after the same reaction time (see Fig. 6). Therefore, for subsequent ox- idation experiments, $6 \mathbf{b}$ was chosen as the medium for the oxidation of sulfides to sulfoxides with $\mathrm{H}_{2} \mathrm{O}_{2}$ at room temperature (Scheme 2). A blank experiment without oxidant was also investigated. No considerable oxidation was observed within $24 \mathrm{~h}$, indicating that the oxygen source for the synthesis of sulfoxide is not air. Maximum yield is achieved after $4 \mathrm{~h}$ reaction time, while the selectivity remains unchanged during the whole reaction time.

To generalize the developed methodology, the oxidation of various sulfides with different substituents was examined. The results are shown in Table 3. All sulfides are effectively oxidized to the corresponding sulfoxides in good to excellent yields using $35 \%$ aqueous hydrogen peroxide at room temperature. Interestingly, dialkyl sulfides (entries 2, 3) are more active, affording very high sulfoxide yields (within $3 \mathrm{~h}$ ). Diaryl sulfides (entries 1, 3-7) are less efficiently oxidized, probably due to steric hindrance. The electronic nature of the substituents has less influence on the yield and selectivity of the sulfoxide products (entries 4-7) in the oxidation of various phenyl-substituted sulfides to the corresponding sulfoxides. It is important to note that another useful feature of the presented protocol

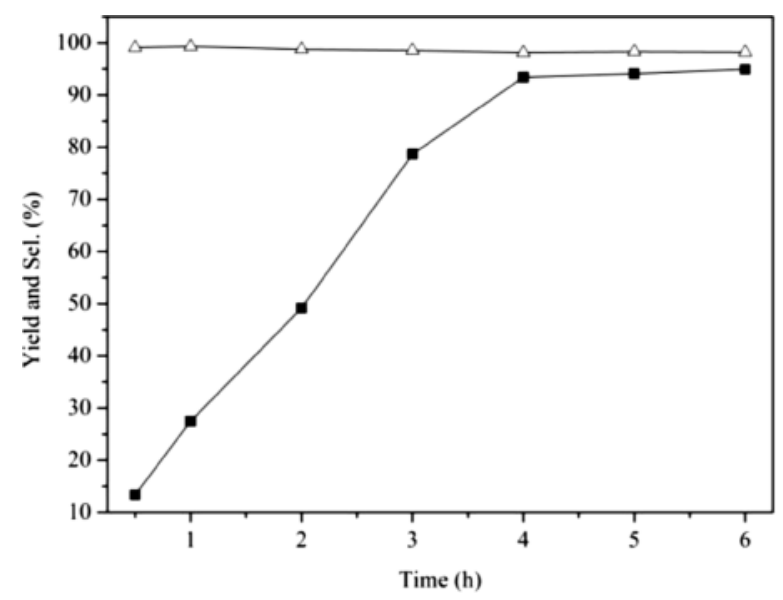

Fig. 6. Time-dependent yield ( $\square)$ and selectivity $(\triangle)$ of methyl phenyl sulfoxide.

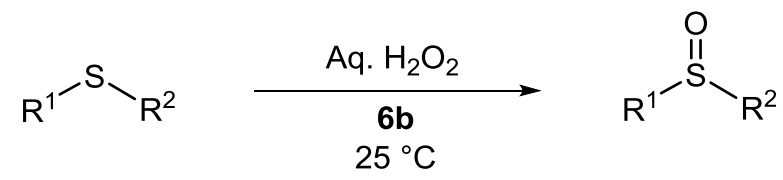

Scheme 2. Oxidation of sulfides to sulfoxides mediated by WCCWCA $6 \mathbf{b}$. 
Table 3. Oxidation of sulfides to sulfoxides with aqueous $\mathrm{H}_{2} \mathrm{O}_{2}$ mediated by WCCWCA $6 \mathbf{b}^{\mathrm{a}}$.

\begin{tabular}{lccccc}
\hline Entry & $\mathrm{R}^{1}$ & $\mathrm{R}^{2}$ & $\begin{array}{c}\text { Time } \\
(\mathrm{h})\end{array}$ & $\begin{array}{c}\text { Yield }^{\mathrm{b}} \\
(\%)\end{array}$ & $\begin{array}{c}\text { Selectivity }^{\mathrm{c}} \\
(\%)\end{array}$ \\
\hline 1 & $\mathrm{Ph}$ & $\mathrm{Me}$ & 4 & 93 & 97 \\
2 & $\mathrm{Me}$ & $\mathrm{Me}$ & 3 & 94 & 98 \\
3 & $n$-Butyl & $n$-Butyl & 4 & 91 & 97 \\
4 & $\mathrm{Ph}$ & Ethyl & 5 & 84 & 96 \\
5 & $\mathrm{Ph}$ & $\mathrm{CH}\left(\mathrm{CH}_{3}\right)_{2}$ & 5 & 80 & 97 \\
6 & $\mathrm{Ph}$ & $\mathrm{CH}_{2} \mathrm{CH}=\mathrm{CH}_{2}$ & 6 & 82 & 96 \\
7 & $\mathrm{Ph}$ & $\mathrm{CH}_{2} \mathrm{CH}_{2} \mathrm{OH}$ & 5 & 86 & 97 \\
\hline
\end{tabular}

a Reaction conditions: $0.5 \mathrm{~mL}$ 6b, $2 \mathrm{mmol}$ substrate, $5 \mathrm{mmol} \mathrm{H}_{2} \mathrm{O}_{2}$ $(30 \%)$ at $25{ }^{\circ} \mathrm{C}$; ${ }^{b}$ isolated yield after column chromatography; ${ }^{\mathrm{c}} \mathrm{de}-$ termined by GC-MS or ${ }^{1} \mathrm{H}$ NMR spectroscopy of the crude reaction mixture.

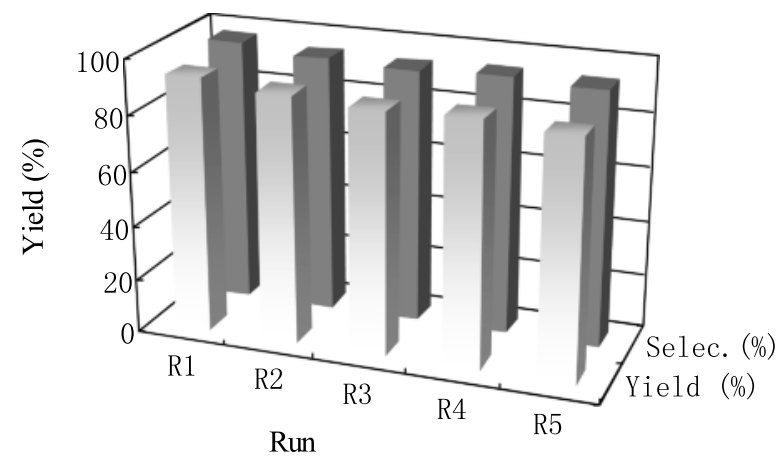

Fig. 7. Oxidation of thioanisole with $\mathrm{H}_{2} \mathrm{O}_{2}$ in $\mathbf{6 b}$ at $25^{\circ} \mathrm{C}$ after five reaction cycles.

is that neither epoxidation of the double bond of allyl phenyl sulfide (entry 6) nor oxidation of the hydroxy group (entry 7) is observed.

The advantage of this oxidation system is the recycling of the WCCWCA. After reaction completion, the product is extracted with $n$-hexane-diethyl ether, and subsequently, $\mathbf{6 b}$ is extracted with $\mathrm{CH}_{2} \mathrm{Cl}_{2}$. The obtained liquid is dried over anhydrous $\mathrm{MgSO}_{4}$ and then dried under high vacuum. Five recycling tests were carried out. The results are summarized in Fig. 7. No significant loss of yield and selectivity was observed after five runs of thioanisol oxidation. This system provides an advantage with respect to recycling and stability when compared to the other systems, which use organic solvents as media for the oxidation of sulfides [86-88].

Regarding the mechanism of this reaction, the interaction between the anion of $\mathbf{6 b}, \mathrm{H}_{2} \mathrm{O}_{2}$ and $\mathrm{H}_{2} \mathrm{O}$ appears to be crucial. It is known that organic sulfides are oxidized by hydrogen peroxide in a het- erolytic process involving nucleophilic attack of the sulfur on the oxygen atom [89]. This also explains why dialkyl sulfides are more easily oxidized than diaryl sulfides. The efficiency of the described oxidizing system can be explained by a specific feature of $\mathbf{6 b}$, which not only acts as solvent but also can be regarded as a promoter of the organic reaction [65]. Because of the electron-withdrawing character of the $\mathrm{CF}_{3}$ group, a hydrogen bond between the fluoride substituents of the $\left[\mathrm{B}\left\{\mathrm{C}_{6} \mathrm{H}_{3}-3,5-\left(\mathrm{CF}_{3}\right)_{2}\right\}_{4}\right]^{-}$anion in $\mathbf{6 b}$ and $\mathrm{H}_{2} \mathrm{O}_{2}$ or $\mathrm{H}_{2} \mathrm{O}$ is formed and prevents any further oxidation to sulfone [90]. Furthermore, the $\left[\mathrm{B}\left\{\mathrm{C}_{6} \mathrm{H}_{3}-3,5-\right.\right.$ $\left.\left.\left(\mathrm{CF}_{3}\right)_{2}\right\}_{4}\right]^{-}$anion is more stable under oxidative conditions than ionic liquids containing $\left[\mathrm{BF}_{4}\right]^{-}$or $\left[\mathrm{PF}_{6}\right]^{-}$ anions, which are sensitive to hydrolysis and release of hydrofluoric acid [91-95].

\section{IR spectroscopy}

In order to further study the interactions between the WCCWCA $6 \mathbf{b}$ and $\mathrm{H}_{2} \mathrm{O} / \mathrm{H}_{2} \mathrm{O}_{2}$ IR and NMR spectroscopy experiments were carried out. For an understanding of the hydrogen bonding to fluoride, $\mathrm{D}_{2} \mathrm{O}$ was applied in the IR measurements. Figs. 8 and 9 show the IR spectra of the $\mathrm{C}-\mathrm{F}$ stretching region of 6b in $\mathrm{D}_{2} \mathrm{O}$ and $\mathrm{H}_{2} \mathrm{O}_{2}$. The $\mathrm{CF}_{3}$ stretching modes are very prominent in the infrared spectra. The local $C_{3 v}$ symmetry should produce only two bands; a higher asymmetric $\left(v_{\mathrm{a}}\right)$ and lower symmetric $\left(v_{\mathrm{s}}\right)$ stretching vibration. Instead, three pronounced bands at 1355 , 1275 and $1119 \mathrm{~cm}^{-1}$ are observed. The first two bands can be interpreted as individual localized CF stretching vibrations, showing different $\mathrm{CF}$ bond lengths. The broad band near $1119 \mathrm{~cm}^{-1}$ appears to be a symmetric stretching mode of different, overlapping CF bands $\left(v>v^{\prime}>v\right)$. This explanation is in agreement with literature data on previously described organic $\mathrm{CF}_{3}$ derivatives [96-104]. While $v$ and $v^{\prime}$ are not shifted, new bands are formed in the region of the $\mathrm{CF}_{3}$ symmetric stretching mode (Fig. 8). The second derivatives of the original spectra are shown in Fig. 9. When adding $\mathrm{D}_{2} \mathrm{O}$ or $\mathrm{H}_{2} \mathrm{O}_{2}$ to $\mathbf{6 b}$, two new bands at 1115 and $1124 \mathrm{~cm}^{-1}$ or 1114 and $1123 \mathrm{~cm}^{-1}$ are formed, respectively. Furthermore, the development of a shoulder near $1085 \mathrm{~cm}^{-1}$ can be seen in Fig. 8, spectra 2a and $3 \mathrm{a}$. In Fig. 9, the band at $1085 \mathrm{~cm}^{-1}$ in $2 \mathrm{~b}$ and $3 \mathrm{~b}$ is getting stronger compared to the pure ionic liquid. These changes can be ascribed to a further distortion of the $\mathrm{CF}_{3}$ local symmetry from $C_{3 v}$ to $C_{1}$ leading to 


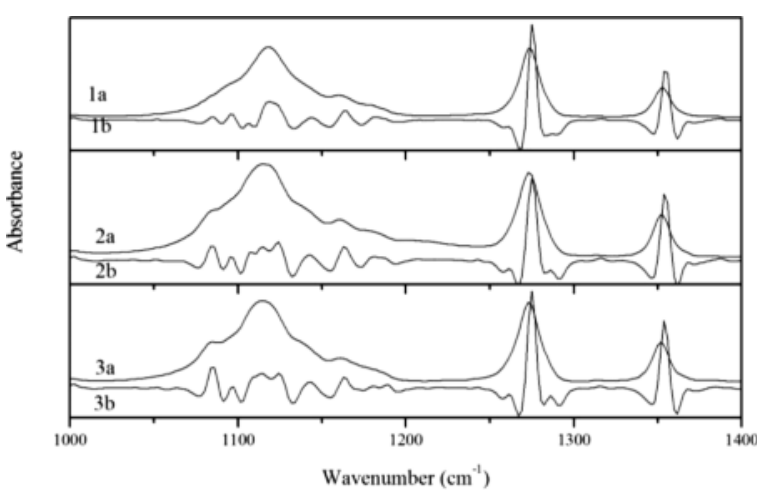

Fig. 8. C-F stretching region of neat $6 \mathbf{b}(1 \mathrm{a}, 1 \mathrm{~b})$, a mixture of $\mathbf{6 b}$ and $\mathrm{D}_{2} \mathrm{O}(2 \mathrm{a}, 2 \mathrm{~b})$ and a mixture of $\mathbf{6 b}$ and $\mathrm{H}_{2} \mathrm{O}_{2}(3 \mathrm{a}, 3 \mathrm{~b})$.

the formation of new spectral features by weak coordination, such as hydrogen bonding between $\mathrm{F}$ of the ionic liquid and hydrogen from $\mathrm{D}_{2} \mathrm{O}$ or $\mathrm{H}_{2} \mathrm{O}_{2}$.

\section{NMR spectroscopy}

Approximate NMR shifts can be indicated for compounds of a known structure and, vice versa, the approximate coordination environment of unknown compounds can be predicted on the basis of chemical shift values [96]. Therefore, ${ }^{11} \mathrm{~B},{ }^{19} \mathrm{~F}$ and ${ }^{31} \mathrm{P}$ NMR spectroscopy were performed to show hydrogen bonding in neat $\mathbf{6 b}$ and in the presence of water or hydrogen peroxide. The ${ }^{11} \mathrm{~B}$ NMR spectrum of $\mathbf{6 b}$ in deuterated DMSO shows one resonance at $-6.58 \mathrm{ppm}$. After adding water, the resonance is slightly shifted to $-6.84 \mathrm{ppm}$, and upon addition of aqueous $\mathrm{H}_{2} \mathrm{O}_{2}$ the signal is shifted to $-6.75 \mathrm{ppm}$ (see Supporting Information available online; see note at the end of the paper for availability). The ${ }^{19} \mathrm{~F}$ NMR spectrum of $\mathbf{6 b}$ shows a signal at $-59.55 \mathrm{ppm}$. When water is added the signal shifts to $-61.29 \mathrm{ppm}$ or splits into two signals at -60.64 and $-61.23 \mathrm{ppm}$ in the case of adding aqueous $\mathrm{H}_{2} \mathrm{O}_{2}$ (see Supporting Information). The slight shift of the $\mathrm{CF}_{3}$ signal points to a change in the chemical environment of the fluorine atoms, pointing to a weak $\mathrm{H}-\mathrm{F}$ interaction. Noteworthy, the signal splitting is not a consequence of the formation of $\mathrm{BF}_{3}$ or $\mathrm{HF}$, which would lead to a significantly different peak position. Additionally, the NMR shifts of the cation of $\mathbf{6} \mathbf{b}$ were also studied. While the ${ }^{31} \mathrm{P}$ NMR spectrum of neat 6b exhibits one resonance at $34.95 \mathrm{ppm}$, upon addition of water the signal moves to $33.43 \mathrm{ppm}$. When

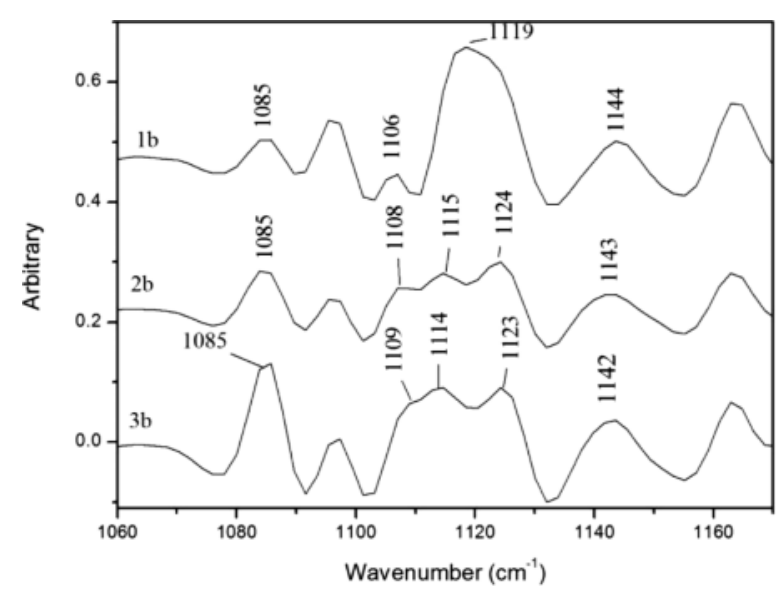

Fig. 9. Second derivative of the $\mathrm{C}-\mathrm{F}$ symmetric stretching region of neat $6 \mathbf{b}(1 b)$, a mixture of $6 \mathbf{b}$ and $\mathrm{D}_{2} \mathrm{O}(2 \mathrm{~b})$ and a mixture of $\mathbf{6 b}$ and $\mathrm{H}_{2} \mathrm{O}_{2}(3 \mathrm{~b})$. The derivative curves were multiplied by a factor of 10 .

aqueous $\mathrm{H}_{2} \mathrm{O}_{2}$ is added the signal of the phosphorus atom is shifted to $33.50 \mathrm{ppm}$, indicating no significant changes of the chemical environment at the central $\mathrm{P}$ atom. Based on the experimental and spectroscopic findings described above, formation of hydrogen bonds between the $\mathrm{CF}_{3}$ groups of the $\left[\mathrm{B}\left\{\mathrm{C}_{6} \mathrm{H}_{3}\right.\right.$ $\left.\left.3,5-\left(\mathrm{CF}_{3}\right)_{2}\right\}_{4}\right]^{-}$anion of $\mathbf{6 b}$ and hydrogen peroxide lead to the activation of $\mathrm{H}_{2} \mathrm{O}_{2}$ and to the oxidation of sulfides to sulfoxides.

\section{Conclusion}

Ionic compounds containing imidazolium, tetrabutylammonium, tetraalkylphosphonium, and 1,1,3,3tetramethylguanidium cations associated with $\left[\mathrm{B}\left(\mathrm{Ar}^{\mathrm{F}}\right)_{4}\right]^{-}$anions have been synthesized and characterized. The synthesis is facile, and the products are obtained in good yields. All salts exhibit high thermal stability. It is shown that the $\left[\mathrm{B}\left(\mathrm{C}_{6} \mathrm{H}_{3}-3,5-\right.\right.$ $\left.\left.\left(\mathrm{CF}_{3}\right)_{2}\right)_{4}\right]^{-}$-containing salts $\mathbf{2 b}-\mathbf{5 b}$ display lower melting points than the $\left[\mathrm{B}\left(\mathrm{C}_{6} \mathrm{~F}_{5}\right)_{4}\right]^{-}$-based salts. The melting points of salts using tetrabutylammonium and 1,1,3,3-tetramethylguanidium as cation are higher than those of any other salts due to the highly symmetric structure. Increasing the size of the ions has a crucial effect on the melting point. Variations of alkyl substituents on the cation can also be used to fine-tune the melting point. In dependence of the structure of the cation, ion pairing via hydrogen-fluorine contacts becomes increasingly relevant, which is particularly 
the case for 1,3-dialkylimidazolium and guanidinium cations. In the absence of such intramolecular interactions the $\left[\mathrm{B}\left(\mathrm{Ar}^{\mathrm{F}}\right)_{4}\right]^{-}$anion can also form H-F bonds with water and hydrogen peroxide, respectively. This leads to an activation of $\mathrm{H}_{2} \mathrm{O}_{2}$ and can be used to mediate the oxidation of sulfides to sulfoxides.

\section{Experimental Section}

\section{General methods}

All preparations and manipulation involving air-sensitive materials were performed using standard Schlenk techniques under argon atmosphere. Solvents were dried by standard procedures $\left(\mathrm{Et}_{2} \mathrm{O}\right.$ over $\mathrm{Na}$ /benzophenone; $\mathrm{CH}_{2} \mathrm{Cl}_{2}$ over $\mathrm{CaH}_{2}$ ), distilled under argon and kept over $4 \AA$ molecular sieves. All chemicals were purchased from Acros Organics or Aldrich and were of analytical grade. They were used as received. NMR spectra were recorded on a Bruker Avance DPX-400 instrument and referenced to the deuterated solvent in the case of the ${ }^{1} \mathrm{H}$ NMR, $\mathrm{C}_{6} \mathrm{~F}_{6}$ for ${ }^{19} \mathrm{~F}$ NMR, $\mathrm{BF}_{3} \cdot \mathrm{OEt}_{2}$ for ${ }^{11} \mathrm{~B}$ NMR, and $\mathrm{H}_{3} \mathrm{PO}_{4}(85 \%)$ for ${ }^{31} \mathrm{P}$ NMR spectra. IR spectra were recorded on a Varian FTIR-670 spectrometer, using a GladiATR accessory with a diamond ATR element. Elemental analyses were obtained from the microanalytical laboratory at Technische Universität München. Catalytic runs were monitored by GC methods on a HewlettPackard instrument HP 5890 Series II equipped with a FID, a Supelco column Alphadex 120 and a Hewlett-Packard integration unit HP 3396 Series II. Thermogravimetry analysis (TGA) was conducted utilizing a Netzsch TG209 system; typically about $10 \mathrm{mg}$ of each sample was heated from 25 to $1000^{\circ} \mathrm{C}$ at $10 \mathrm{~K} \mathrm{~min}^{-1}$. Differential scanning analysis (DSC) was performed on a DSCQ2000 instrument (Waters) in a temperature range from -150 to $200^{\circ} \mathrm{C}$ at $10 \mathrm{~K} \mathrm{~min}^{-1}$. Melting points were measured by MPM-H2 melting point meters. TLC was performed on silica gel $60 \mathrm{~F} 254$ plates form E. Merck. Silica gel $(0.06-0.2 \mathrm{~mm} 60 \AA$ ) was used for column chromatography.

\section{Synthesis of WCCWCAs}

General procedures for the synthesis of $\mathrm{Li}\left[\mathrm{B}\left(\mathrm{C}_{6} F_{5}\right)_{4}\right]$, $\mathrm{Li}\left[\mathrm{B}\left(\mathrm{C}_{6} \mathrm{H}_{3}-3,5-\left(\mathrm{CF}_{3}\right)_{2}\right)_{4}\right], \mathrm{Ag}\left[\mathrm{B}\left(\mathrm{C}_{6} F_{5}\right)_{4}\right]$, and $\mathrm{Ag}\left[\mathrm{B}\left(\mathrm{C}_{6} \mathrm{H}_{3}-3,5-\left(\mathrm{CF}_{3}\right)_{2}\right)_{4}\right]$

A $2.5 \mathrm{M}$ solution of $n$-butyl lithium in hexane $(17.82 \mathrm{~mL})$ was added slowly to a solution of bromopentafluorobenzene $(5 \mathrm{~mL}, 40 \mathrm{mmol})$ or 3,5-bis(trifluoromethyl)-5bromobenzene $(7 \mathrm{~mL}, 40 \mathrm{mmol})$ in a mixture of diethyl ether $(40 \mathrm{~mL})$ at $-78^{\circ} \mathrm{C}$, and the mixture was stirred for $1 \mathrm{~h}$. This was followed by the dropwise addition of $\mathrm{BCl}_{3}$
(11.8 mL, $11.8 \mathrm{mmol})$ dissolved in diethyl ether (20 mL). After $1 \mathrm{~h}$, the resulting suspension was warmed slowly to room temperature. The product $\mathrm{Li}\left[\mathrm{B}\left(\mathrm{C}_{6} \mathrm{~F}_{5}\right)_{4}\right]$ or $\mathrm{Li}\left[\mathrm{B}\left\{\mathrm{C}_{6} \mathrm{H}_{3}-3,5\right.\right.$ $\left.\left.\left(\mathrm{CF}_{3}\right)_{2}\right\}_{4}\right]$ was separated by filtration, washed with pentane for several times, and then dried under vacuum for one day. $\mathrm{Ag}\left[\mathrm{B}\left(\mathrm{C}_{6} \mathrm{~F}_{5}\right)_{4}\right]$ and $\mathrm{Ag}\left[\mathrm{B}\left(\mathrm{C}_{6} \mathrm{H}_{3}-3,5-\left(\mathrm{CF}_{3}\right)_{2}\right)_{4}\right]$ were prepared according to a previously published procedure [72].

General procedure for the synthesis of $1 a-7 a$

1 equiv. $\mathrm{Li}\left[\mathrm{B}\left(\mathrm{C}_{6} \mathrm{~F}_{5}\right)_{4}\right]$ and 1 equiv. [WCC]X were weighed in two different Schlenk tubes and dissolved in $\mathrm{CH}_{2} \mathrm{Cl}_{2}$. The two solutions were mixed and stirred for $2 \mathrm{~h}$ at room temperature, and then filtered. The solvent was removed under high vacuum for $4 \mathrm{~h}$. The product was washed three times with dry $n$-hexane and then dried under vacuum for one day.

\section{Improved procedure for the synthesis of $1 \mathbf{1}-7 \mathbf{a}$}

To a mixture of equimolar amounts of $\mathrm{Ag}\left[\mathrm{B}\left(\mathrm{C}_{6} \mathrm{~F}_{5}\right)_{4}\right]$ and [WCC]X dry $\mathrm{CH}_{2} \mathrm{Cl}_{2}(20 \mathrm{~mL})$ was added. The mixture was stirred under exclusion of light at room temperature for $10 \mathrm{~min}$. The precipitate was removed by filtration, and the filtrate was dried for $4 \mathrm{~h}$ under high vacuum. The product was washed several times with $n$-hexane and dried under vacuum for one day.

Experimental data for $1 \mathrm{a}: \mathrm{Ag}\left[\mathrm{B}\left(\mathrm{C}_{6} \mathrm{~F}_{5}\right)_{4}\right](0.787 \mathrm{~g}, 1 \mathrm{mmol})$, [Bmim] Br (0.218 g, $1 \mathrm{mmol})$; isolated yield: $0.73 \mathrm{~g} \mathrm{(89 \% ).}$ - ${ }^{1} \mathrm{H}$ NMR ([D 6 DMSO, $400 \mathrm{MHz}$, r.t., ppm): $\delta=0.89$ $(\mathrm{t}, 3 \mathrm{H}), 1.25(\mathrm{~m}, 2 \mathrm{H}), 1.76(\mathrm{~m}, 2 \mathrm{H}), 3.85(\mathrm{~s}, 3 \mathrm{H}), 4.16$ $(\mathrm{t}, 2 \mathrm{H}), 7.71(\mathrm{~m}, 1 \mathrm{H}), 7.77(\mathrm{~m}, 1 \mathrm{H}), 9.12(\mathrm{~s}, 1 \mathrm{H}),-{ }^{19} \mathrm{~F}$ NMR ([D 6 DMSO, $377 \mathrm{MHz}$, r.t., ppm): $\delta=-131.26$ $(\mathrm{s}, 8 \mathrm{~F}),-161.66(\mathrm{t}, 4 \mathrm{~F}),-165.60(\mathrm{t}, 8 \mathrm{~F}) .-{ }^{11} \mathrm{~B}$ NMR ([D $]$ DMSO, $128 \mathrm{MHz}$, r.t., ppm): $\delta=-16.7$ (s). - IR $\left(\mathrm{cm}^{-1}\right): v=480(\mathrm{w}), 573(\mathrm{w}), 660(\mathrm{~m}), 683(\mathrm{~m}), 739(\mathrm{~m})$, 772 (m), 974 (vs), 1082 (vs), 1272 (m), 1373 (w), 1486 (vs), 1513 (s), 1642 (m), 1953 (w), 2159 (w), 2545 (vw). - Elemental analysis for $\mathrm{C}_{32} \mathrm{H}_{14} \mathrm{~N}_{2} \mathrm{BF}_{20}(\%)$ : calcd. $\mathrm{C} 46.91, \mathrm{H}$ 1.97, N 3.42; found C 46.25, H 2.10, N 3.87.

Experimental data for $2 a$ : $\operatorname{Ag}\left[\mathrm{B}\left(\mathrm{C}_{6} \mathrm{~F}_{5}\right)_{4}\right](0.787 \mathrm{~g}, 1 \mathrm{mmol})$, [Bdmim] $\mathrm{Br}(0.223 \mathrm{~g}, 1 \mathrm{mmol})$; isolated yield: $0.76 \mathrm{~g} \mathrm{(92 \% ).}$ $-{ }^{1} \mathrm{H}$ NMR ([D $]$ DMSO, $400 \mathrm{MHz}$, r. t., ppm): $\delta=0.89$ (t, $3 \mathrm{H}), 1.27(\mathrm{~m}, 2 \mathrm{H}), 1.68(\mathrm{~m}, 2 \mathrm{H}), 2.58(\mathrm{~s}, 3 \mathrm{H}), 3.75(\mathrm{~s}$, $3 \mathrm{H}), 4.11(\mathrm{t}, 2 \mathrm{H}), 7.61(\mathrm{~m}, 1 \mathrm{H}), 7.64(\mathrm{~m}, 1 \mathrm{H}) .-{ }^{19} \mathrm{~F} \mathrm{NMR}$ ([D $]$ DMSO, $377 \mathrm{MHz}$, r.t., ppm): $\delta=-132.42$ (s, 8F), -161.54 (t, 4F), -166.02 (t, 8F). - ${ }^{11} \mathrm{~B}$ NMR ([D 6 DMSO, $128 \mathrm{MHz}$, r.t., ppm): $\delta=-16.8$ (s). $-\mathrm{IR}\left(\mathrm{cm}^{-1}\right): v=477$ (vw), $573(\mathrm{w}), 621(\mathrm{w}), 659(\mathrm{~m}), 683(\mathrm{w}), 830(\mathrm{~m}), 957(\mathrm{vs})$, 1081 (s), 1163 (m), 1274 (m), 1374 (w), 1458 (vs), 1512 (s), 1567 (w), 1592 (w), 1642 (m), 1957 (m), 2158 (m), 2547 
(w). - Elemental analysis for $\mathrm{C}_{33} \mathrm{H}_{17} \mathrm{~N}_{2} \mathrm{BF}_{20}(\%)$ : calcd. $\mathrm{C}$ 47.56, H 2.18, N 3.36; found C 46.63, H 2.48, N 3.89 .

Experimental data for $3 a: \operatorname{Ag}\left[\mathrm{B}\left(\mathrm{C}_{6} \mathrm{~F}_{5}\right)_{4}\right](0.787 \mathrm{~g}, 1 \mathrm{mmol})$, [ $\left.\mathrm{C}_{12} \mathrm{mim}\right] \mathrm{Br}(0.331 \mathrm{~g}, 1 \mathrm{mmol})$; isolated yield: $0.87 \mathrm{~g} \mathrm{(93 \% ).}$ - ${ }^{1} \mathrm{H}$ NMR ([D $]$ DMSO, $400 \mathrm{MHz}$, r.t., ppm): $\delta=0.78$ $(\mathrm{t}, 3 \mathrm{H}), 1.20(\mathrm{~m}, 18 \mathrm{H}), 1.75(\mathrm{~m}, 2 \mathrm{H}), 3.83(3 \mathrm{H}), 4.13(\mathrm{t}$, 2H), $7.68(\mathrm{~s}, 1 \mathrm{H}), 7.73(\mathrm{~s}, 1 \mathrm{H}), 9.09(\mathrm{~s}, 1 \mathrm{H}),-{ }^{19} \mathrm{~F} \mathrm{NMR}$ ([D $]$ DMSO, $377 \mathrm{MHz}$, r.t., ppm): $\delta=-130.28(\mathrm{~s}, 8 \mathrm{~F})$, $-159.55(\mathrm{t}, 4 \mathrm{~F}),-164.01(\mathrm{t}, 8 \mathrm{~F}) .-{ }^{11} \mathrm{~B}$ NMR $\left(\left[\mathrm{D}_{6}\right] \mathrm{DMSO}\right.$, $128 \mathrm{MHz}$, r. t., ppm): $\delta=-16.51$ (s). $-\mathrm{IR}\left(\mathrm{cm}^{-1}\right): v=475$ (vw), $573(\mathrm{~m}), 610(\mathrm{w}), 623(\mathrm{~m}), 660(\mathrm{~s}), 682(\mathrm{~m}), 734(\mathrm{w})$, $756(\mathrm{~m}), 773(\mathrm{~m}), 800$ (vw), 831 (w), 976 (vs), 1080 (vs), 1165 (m), 1274 (m), 1461 (vs), 1514 (s), 1563 (w), 1589 (w), $1644(\mathrm{~m}), 2856$ (w), 2927 (w). - Elemental analysis for $\mathrm{C}_{40} \mathrm{H}_{32} \mathrm{~N}_{2} \mathrm{BF}_{20}$ (\%): calcd. C 51.58, H 3.46, N 3.01; found C 51.39, H 3.63, N 3.16 .

Experimental data for $4 a$ : $\mathrm{Ag}\left[\mathrm{B}\left(\mathrm{C}_{6} \mathrm{~F}_{5}\right)_{4}\right](0.787 \mathrm{~g}, 1 \mathrm{mmol})$, $\left[\mathrm{NBu}_{4}\right] \mathrm{Br}(0.322 \mathrm{~g}, 1 \mathrm{mmol})$; isolated yield: $0.86 \mathrm{~g}(93 \%)$. ${ }^{1} \mathrm{H} \mathrm{NMR}\left(\mathrm{CDCl}_{3}, 400 \mathrm{MHz}\right.$, r. t., ppm): $\delta=0.97(\mathrm{t}, 12 \mathrm{H})$, $1.25(\mathrm{~m}, 8 \mathrm{H}), 1.53(\mathrm{~m}, 8 \mathrm{H}), 3.05(\mathrm{~m}, 8 \mathrm{H}) .-{ }^{19} \mathrm{~F} \mathrm{NMR}$ ([D $\left.\mathrm{D}_{6}\right] \mathrm{DMSO}, 377 \mathrm{MHz}$, r.t., ppm): $\delta=-131.08$ (s, 8F), $-160.51(\mathrm{t}, 4 \mathrm{~F}),-161.40(\mathrm{t}, 8 \mathrm{~F}) .-{ }^{11} \mathrm{~B}$ NMR ([D 6 DMSO, $128 \mathrm{MHz}$, r.t., ppm): $\delta=-16.37$ (s). $-\mathrm{IR}\left(\mathrm{cm}^{-1}\right): v=476$ (w), $574(\mathrm{w}), 660(\mathrm{~m}), 682(\mathrm{~m}), 773(\mathrm{w}), 977(\mathrm{vs}), 1085(\mathrm{~s})$, 1272 (m), 1461 (vs), 1513 (s), 1643 (w), 1960 (w), 2169 (w), $2878(w), 2963(w) .-$ Elemental analysis for $\mathrm{C}_{40} \mathrm{H}_{36} \mathrm{BF}_{20} \mathrm{~N}$ (\%): calcd. C 52.14, H 3.94, N 1.52; found C 51.07, H 4.10, N 1.66.

Experimental data for $5 \mathrm{a}: \mathrm{Ag}\left[\mathrm{B}\left(\mathrm{C}_{6} \mathrm{~F}_{5}\right)_{4}\right](0.787 \mathrm{~g}, 1 \mathrm{mmol})$, $\left[\mathrm{PBu}_{4}\right] \mathrm{Br}(0.338 \mathrm{~g}, 1 \mathrm{mmol})$; isolated yield: $0.82 \mathrm{~g}(87 \%)$. ${ }^{1} \mathrm{H}$ NMR ([D 6 DMSO, $400 \mathrm{MHz}$, r.t., ppm): $\delta=0.86(\mathrm{~m}$, $12 \mathrm{H}), 1.38(\mathrm{~m}, 16 \mathrm{H}), 2.14(\mathrm{~m}, 8 \mathrm{H}) .-{ }^{19} \mathrm{~F} \mathrm{NMR}\left(\left[\mathrm{D}_{6}\right] \mathrm{DMSO}\right.$, $377 \mathrm{MHz}$, r. t., ppm): $\delta=-130.20(\mathrm{~s}, 8 \mathrm{~F}),-159.07$ (t, 4F), $-163.72(\mathrm{t}, 8 \mathrm{~F}) .-{ }^{11} \mathrm{~B}$ NMR ([D $]$ DMSO, $128 \mathrm{MHz}$, r.t., ppm): $\delta=-16.47$ (s). $-{ }^{31} \mathrm{P}$ NMR ([D 6$]$ DMSO, $162 \mathrm{MHz}$, r. t., ppm): $\delta=29.74(\mathrm{~s}) .-\mathrm{IR}\left(\mathrm{cm}^{-1}\right): v=574(\mathrm{w}), 660(\mathrm{~m})$, $683(\mathrm{w}), 755(\mathrm{~m}), 772(\mathrm{~m}), 906$ (m), 975 (vs), 1082 (vs), 1273 (w), 1382 (vw), 1459 (vs), 1512 (s), 1642 (m), 1958 (vw), 2159 (vw), 2873 (w), 2932 (w), 2960 (w). - Elemental analysis for $\mathrm{C}_{40} \mathrm{H}_{36} \mathrm{BF}_{20} \mathrm{P}(\%)$ : calcd. C 51.19, H 3.87; found $\mathrm{C} 50.27, \mathrm{H} 4.03$.

Experimental data for $\boldsymbol{6} \boldsymbol{a}: \operatorname{Ag}\left[\mathrm{B}\left(\mathrm{C}_{6} \mathrm{~F}_{5}\right)_{4}\right](0.787 \mathrm{~g}, 1 \mathrm{mmol})$, $\left[\mathrm{P}_{4,4,4,14}\right] \mathrm{Cl}(0.434 \mathrm{~g}, 1 \mathrm{mmol})$; isolated yield: $0.92 \mathrm{~g}(85 \%)$. $-{ }^{1} \mathrm{H}$ NMR ([D $]$ DMSO, $400 \mathrm{MHz}$, r.t., ppm): $\delta=078(\mathrm{t}$, $3 \mathrm{H}), 0.88(\mathrm{t}, 9 \mathrm{H}), 1.21(\mathrm{~m}, 20 \mathrm{H}), 1.43(\mathrm{~m}, 16 \mathrm{H}), 2.17(\mathrm{~m}$, $8 \mathrm{H}) .-{ }^{19} \mathrm{~F}$ NMR ([D 6 DMSO, $377 \mathrm{MHz}$, r.t., ppm): $\delta=$ -130.23 (s, 8F), -160.21 (t, 4F), -164.35 (t, 8F,). ${ }^{11} \mathrm{~B}$ NMR ([D 6 DMSO, $128 \mathrm{MHz}$, r.t., ppm): $\delta=-16.51$ (s).
- ${ }^{31} \mathrm{P}$ NMR ([D 6 DMSO, $162 \mathrm{MHz}$, r.t., ppm): $\delta=33.77$ (s). - IR $\left(\mathrm{cm}^{-1}\right): v=475(\mathrm{vw}), 573(\mathrm{w}), 602(\mathrm{w}), 610(\mathrm{w})$, $660(\mathrm{~m}), 683(\mathrm{w}), 726(\mathrm{vw}), 755(\mathrm{~m}), 774(\mathrm{vs}), 909$ (vw), 977 (vs), 1083 (vs), 1274 (m), 1373 (vw), 1461 (vs), 1512 (s), $1642(\mathrm{~m}), 2857(\mathrm{w}), 2929(\mathrm{w})$. - Elemental analysis for $\mathrm{C}_{50} \mathrm{H}_{56} \mathrm{BF}_{20} \mathrm{P}(\%)$ : calcd. C 55.67, H 5.23; found C 55.66, H 5.96.

Experimental data for $7 a$ : $\operatorname{Ag}\left[\mathrm{B}\left(\mathrm{C}_{6} \mathrm{~F}_{5}\right)_{4}\right](0.787 \mathrm{~g}, 1 \mathrm{mmol})$, [TMG]Cl $(0.151 \mathrm{~g}, 1 \mathrm{mmol})$; isolated yield: $0.75 \mathrm{~g}(94 \%)$. $-{ }^{1} \mathrm{H}$ NMR ([D $]$ DMSO, $400 \mathrm{MHz}$, r. t., ppm): $\delta=1.89$ (s, $12 \mathrm{H}), 7.89$ (s, 2H). $-{ }^{19} \mathrm{~F}$ NMR ([D 6 DMSO, $377 \mathrm{MHz}$, r. t., $\mathrm{ppm}): \delta=-130.32$ (s, 8F), -159.30 (t, 4F), -163.91 (t, 8F). $-{ }^{11} \mathrm{~B}$ NMR $\left(\left[\mathrm{D}_{6}\right] \mathrm{DMSO}, 128 \mathrm{MHz}\right.$, r.t., ppm): $\delta=-16.49$ (s). - IR $\left(\mathrm{cm}^{-1}\right): v=440(\mathrm{w}), 661(\mathrm{~s}), 756(\mathrm{w}), 774(\mathrm{~m})$, 976 (vs), 1080 (s), 1276 (m), 1460 (vs), 1511 (s), 1628 (s), 1958 (w), 2158 (w), 3433 (vw). - Elemental analysis for $\mathrm{C}_{29} \mathrm{H}_{14} \mathrm{~N}_{3} \mathrm{BF}_{20}(\%)$ : calcd. C 43.80, H 1.77, N 5.28; found C 43.52, H 1.86, N 5.38.

\section{General procedure for the synthesis of $\mathbf{1 b}-\mathbf{7 b}$}

In a Schlenk flask, to a mixture of equimolar amounts of $\mathrm{Ag}\left[\mathrm{B}\left(\mathrm{C}_{6} \mathrm{H}_{3}-3,5-\left(\mathrm{CF}_{3}\right)_{2}\right)_{4}\right]$ and [WCC]X dry $\mathrm{CH}_{2} \mathrm{Cl}_{2}$ $(20 \mathrm{~mL})$ was added. The mixture was stirred under exclusion of light at room temperature for $10 \mathrm{~min}$. The precipitate was removed by filtration, and the filtrate was dried in high vacuum for $4 \mathrm{~h}$. The product was washed several times with $n$-hexane and dried under vacuum for one day.

Experimental data for $\mathbf{1 b}$ : $\mathrm{Ag}\left[\mathrm{B}\left\{\mathrm{C}_{6} \mathrm{H}_{3}-3,5-\left(\mathrm{CF}_{3}\right)_{2}\right\}_{4}\right]$ $(0.971 \mathrm{~g}, 1 \mathrm{mmol}),\left[\mathrm{C}_{4} \mathrm{mim}\right] \mathrm{Br}(0.218 \mathrm{~g}, 1 \mathrm{mmol})$; isolated yield: $0.95 \mathrm{~g}(95 \%) .-{ }^{1} \mathrm{H}$ NMR ([D 6 DMSO, $400 \mathrm{MHz}$, r.t., ppm): $\delta=0.89(\mathrm{t}, 3 \mathrm{H}), 1.26(\mathrm{~m}, 2 \mathrm{H}), 1.75(\mathrm{~m}, 2 \mathrm{H})$, $3.84(\mathrm{~s}, 3 \mathrm{H}), 4.15(\mathrm{t}, 2 \mathrm{H}), 7.62(\mathrm{~m}, 8 \mathrm{H}), 7.70(\mathrm{~m}, 4 \mathrm{H})$, $7.73(\mathrm{~m}, 1 \mathrm{H}), 7.71(\mathrm{~m}, 1 \mathrm{H}), 9.11(\mathrm{~s}, 1 \mathrm{H}) .-{ }^{19} \mathrm{~F}$ NMR ([D6]DMSO, $377 \mathrm{MHz}$, r.t., ppm): $\delta=-59.96(\mathrm{~s}, 6 \mathrm{~F}) .-{ }^{11} \mathrm{~B}$ NMR ([D 6 DMSO, $128 \mathrm{MHz}$, r. t., ppm): $\delta=-6.58(\mathrm{~s}) .-\mathrm{IR}$ $\left(\mathrm{cm}^{-1}\right): v=448(\mathrm{w}), 621(\mathrm{~m}), 669(\mathrm{~s}), 712(\mathrm{~s}), 743(\mathrm{~m}), 837$ (m), 887 (m), 1109 (vs), 1272 (vs), 1353 (s), 1568 (vw), 1608 (vw), 2961 (vw). - Elemental analysis for $\mathrm{C}_{40} \mathrm{H}_{28} \mathrm{~N}_{2} \mathrm{BF}_{24}$ (\%): calcd. C 47.88, H 2.81, N 2.79; found C 47.54, H 2.84, N 3.08.

Experimental data for $2 \boldsymbol{b}$ : $\mathrm{Ag}\left[\mathrm{B}\left\{\mathrm{C}_{6} \mathrm{H}_{3}-3,5-\left(\mathrm{CF}_{3}\right)_{2}\right\}_{4}\right]$ $(0.971 \mathrm{~g}, 1 \mathrm{mmol})$, [Bdmin]Br $(0.223 \mathrm{~g}, 1 \mathrm{mmol})$; isolated yield: $0.97 \mathrm{~g}(95 \%) .-{ }^{1} \mathrm{H}$ NMR ([D 6 DMSO, $400 \mathrm{MHz}$, r. t., ppm): $\delta=0.87(\mathrm{t}, 3 \mathrm{H}), 1.25(\mathrm{~m}, 2 \mathrm{H}), 1.64(\mathrm{~m}, 2 \mathrm{H})$, $2.48(\mathrm{~s}, 3 \mathrm{H}), 3.73(\mathrm{~s}, 3 \mathrm{H}), 4.08(\mathrm{t}, 2 \mathrm{H}), 7.61(\mathrm{~m}, 12 \mathrm{H}), 7.62$ $(\mathrm{m}, 2 \mathrm{H}) .-{ }^{19} \mathrm{~F}$ NMR ([D 6 DMSO, $377 \mathrm{MHz}$, r.t., ppm): $\delta=-59.55(\mathrm{~s}, 6 \mathrm{~F}) .-{ }^{11} \mathrm{~B}$ NMR ([D 6$] \mathrm{DMSO}, 128 \mathrm{MHz}$, r. t., $\mathrm{ppm}): \delta=-6.59(\mathrm{~s}) .-\mathrm{IR}\left(\mathrm{cm}^{-1}\right): v=669(\mathrm{vs}), 715(\mathrm{~s}), 742$ (m), 838 (m), 889 (s), 1115 (vs), 1274 (vs), 1352 (s), 1462 
(w), 1535 (vw), 2193 (w), 2959 (vw). - Elemental analysis for $\mathrm{C}_{41} \mathrm{H}_{30} \mathrm{~N}_{2} \mathrm{BF}_{24}(\%)$ : calcd. C48.40, H 2.97, N 2.75; found C 47.70, H 2.96, N 3.03.

Experimental data for $3 \boldsymbol{b}: \quad \mathrm{Ag}\left[\mathrm{B}\left\{\mathrm{C}_{6} \mathrm{H}_{3}-3,5-\left(\mathrm{CF}_{3}\right)_{2}\right\}_{4}\right]$ $(0.971 \mathrm{~g}, 1 \mathrm{mmol}),\left[\mathrm{C}_{12} \mathrm{mim}\right] \mathrm{Br}(0.331 \mathrm{~g}, 1 \mathrm{mmol})$; isolated yield: $1.03 \mathrm{~g}(93 \%) .-{ }^{1} \mathrm{H}$ NMR ([D 6 DMSO, $400 \mathrm{MHz}$, r. t., ppm): $\delta=0.72(\mathrm{t}, 3 \mathrm{H}), 1.16(\mathrm{~m}, 18 \mathrm{H}), 1.75(\mathrm{~m}, 2 \mathrm{H}), 3.84$ $(3 \mathrm{H}), 4.13(\mathrm{t}, 2 \mathrm{H}), 7.69(\mathrm{~m}, 12 \mathrm{H}), 7.74(\mathrm{~s}, 1 \mathrm{H}), 7.75(\mathrm{~s}, 1 \mathrm{H})$, $9.11(\mathrm{~s}, 1 \mathrm{H}) .-{ }^{19} \mathrm{~F}$ NMR ([D 6$]$ DMSO, $377 \mathrm{MHz}$, r. t., ppm): $\delta=-60.03(\mathrm{~s}, 6 \mathrm{~F}) .-{ }^{11} \mathrm{~B}$ NMR $\left(\left[\mathrm{D}_{6}\right] \mathrm{DMSO}, 128 \mathrm{MHz}\right.$, r.t., ppm): $\delta=-6.54(\mathrm{~s}) .-\mathrm{IR}\left(\mathrm{cm}^{-1}\right): v=446(\mathrm{~m}), 580(\mathrm{vw})$, $622(\mathrm{w}), 667(\mathrm{~s}), 682(\mathrm{~m}), 707(\mathrm{~m}), 715(\mathrm{~m}), 742(\mathrm{w}), 838(\mathrm{~m})$, 888 (s), 899 (m), 949 (vw), 1114 (vs), 1158 (vs), 1272 (vs), 1353 (vs), 1466 (vw), 1570 (vw), 1610 (vw), 2860 (w), 2934 (w). - Elemental analysis for $\mathrm{C}_{48} \mathrm{H}_{44} \mathrm{~N}_{2} \mathrm{BF}_{24}(\%)$ : calcd. C 51.68, H 3.98, N 2.51; found C 51.81, H 3.90, N 2.52.

Experimental data for $\quad \mathbf{b} \boldsymbol{b}: \quad \mathrm{Ag}\left[\mathrm{B}\left\{\mathrm{C}_{6} \mathrm{H}_{3}-3,5-\left(\mathrm{CF}_{3}\right)_{2}\right\}_{4}\right]$ $(0.971 \mathrm{~g}, 1 \mathrm{mmol}),\left[\mathrm{NBu}_{4}\right] \mathrm{Br}(0.322 \mathrm{~g}, 1 \mathrm{mmol})$; isolated yield: $1.04 \mathrm{~g}(94 \%) .-{ }^{1} \mathrm{H}$ NMR ([D $]$ DMSO, $400 \mathrm{MHz}$, r. t., ppm): $\delta=0.88(\mathrm{t}, 12 \mathrm{H}), 1.27(\mathrm{~m}, 8 \mathrm{H}), 1.55(\mathrm{~m}, 8 \mathrm{H}), 3.15$ $(\mathrm{m}, 8 \mathrm{H}), 7.58(\mathrm{~m}, 12 \mathrm{H}) .-{ }^{19} \mathrm{~F}$ NMR ([D 6$] \mathrm{DMSO}, 377 \mathrm{MHz}$, r.t., ppm): $\delta=-59.87$ (s, 6F). $-{ }^{11} \mathrm{~B}$ NMR ([D 6$]$ DMSO, $128 \mathrm{MHz}$, r.t., ppm): $\delta=-6.81(\mathrm{~s}) .-\mathrm{IR}\left(\mathrm{cm}^{-1}\right): v=450$ (vw), 670 (s), 712 (s), 799 (m), 838 (m), 889 (m), 1117 (vs), 1271 (vs), 1353 (s), 1470 (w), 1608 (vw), 2179 (w), 2964 (w). - Elemental analysis for $\mathrm{C}_{48} \mathrm{H}_{48} \mathrm{NBF}_{24}(\%)$ : calcd. C 52.14, H 4.38, N 1.27; found C 51.81, H 4.70, N 1.44.

Experimental data for 5b: $\mathrm{Ag}\left[\mathrm{B}\left\{\mathrm{C}_{6} \mathrm{H}_{3}-3,5-\left(\mathrm{CF}_{3}\right)_{2}\right\}_{4}\right]$ $(0.971 \mathrm{~g}, 1 \mathrm{mmol}),\left[\mathrm{PBu}_{4}\right] \mathrm{Br}(0.338 \mathrm{~g}, 1 \mathrm{mmol})$; isolated yield: $1.02 \mathrm{~g}(91 \%) .-{ }^{1} \mathrm{H}$ NMR ([D 6$] \mathrm{DMSO}, 400 \mathrm{MHz}$, r. t., ppm): $\delta=0.82(\mathrm{~m}, 12 \mathrm{H}), 1.36(\mathrm{~m}, 16 \mathrm{H}), 2.10(\mathrm{~m}, 8 \mathrm{H}) ; 7.57$ $(\mathrm{m}, 12 \mathrm{H}) .-{ }^{19} \mathrm{~F}$ NMR ([D 6 DMSO, $377 \mathrm{MHz}$, r.t., ppm): $\delta=-59.66(\mathrm{~s}, 6 \mathrm{~F}) .-{ }^{11} \mathrm{~B}$ NMR ([D $]$ DMSO, $128 \mathrm{MHz}$, r. t., ppm): $\delta=-6.59$ (s). $-{ }^{31} \mathrm{P}$ NMR ([D 6 DMSO, $162 \mathrm{MHz}$, r. t., ppm): $\delta=33.76$ (s). - IR $\left(\mathrm{cm}^{-1}\right): v=447$ (vw), 667 (m), $712(\mathrm{~m}), 837$ (w), 886 (m), 1114 (vs), 1272 (vs), 1353 (s), 1465 (w), 1610 (vw), 2542 (vw), 2875 (vw), 2963 (vw). - Elemental analysis for $\mathrm{C}_{48} \mathrm{H}_{48} \mathrm{BF}_{20} \mathrm{P}(\%)$ : calcd. C 51.35, $\mathrm{H}$ 4.31; found: C 51.07, H 4.46.

Experimental data for $\boldsymbol{6} \boldsymbol{b}: \operatorname{Ag}\left[\mathrm{B}\left\{\mathrm{C}_{6} \mathrm{H}_{3}-3,5-\left(\mathrm{CF}_{3}\right)_{2}\right\}_{4}\right]$ $(0.971 \mathrm{~g}, 1 \mathrm{mmol}),\left[\mathrm{P}_{4,4,4,14}\right] \mathrm{Cl}(0.434 \mathrm{~g}, 1 \mathrm{mmol})$; isolated yield: $1.15 \mathrm{~g}(91 \%)$. $-{ }^{1} \mathrm{H}$ NMR ([D $]$ DMSO, $400 \mathrm{MHz}$, r. t., ppm): $\delta=0.73(\mathrm{t}, 3 \mathrm{H}), 0.84(\mathrm{t}, 9 \mathrm{H}), 1.16(\mathrm{~m}, 20 \mathrm{H})$, $1.40(\mathrm{~m}, 16 \mathrm{H}), 2.13(\mathrm{~m}, 8 \mathrm{H}), 7.57(\mathrm{~m}, 12 \mathrm{H}) .-{ }^{19} \mathrm{~F}$ NMR ([D6]DMSO, $377 \mathrm{MHz}$, r. t., ppm): $\delta=-59.55$ (s, 6F). $-{ }^{11} \mathrm{~B}$ NMR ([D 6 DMSO, $128 \mathrm{MHz}$, r.t., ppm): $\delta=-6.58$ (s). ${ }^{31} \mathrm{P}$ NMR ([D $]$ DMSO, $162 \mathrm{MHz}$, r. t., ppm): $\delta=33.54$ (s). IR $\left(\mathrm{cm}^{-1}\right): v=403(\mathrm{w}), 450(\mathrm{w}), 618(\mathrm{vw}), 669(\mathrm{~s}), 681(\mathrm{~m})$,
710 (s), 744 (vw), 838 (m), 887 (m), 934 (vw), 1001 (vw), 1112 (vs), 1161 (vs), 1274 (vs), 1351 (s), 1468 (w), 1608 (w), 2858 (w), 2927 (w). - Elemental analysis for $\mathrm{C}_{58} \mathrm{H}_{68} \mathrm{BF}_{24} \mathrm{P}$ (\%): calcd. C 55.16, H 5.43; found C 55.79, H 5.81.

Experimental data for $7 \boldsymbol{b}$ : $\quad \operatorname{Ag}\left[\mathrm{B}\left\{\mathrm{C}_{6} \mathrm{H}_{3}-3,5-\left(\mathrm{CF}_{3}\right)_{2}\right\}_{4}\right]$ $(0.971 \mathrm{~g}, 1 \mathrm{mmol}),[\mathrm{TMG}] \mathrm{Cl}(0.151 \mathrm{~g}, 1 \mathrm{mmol})$; isolated yield: $0.93 \mathrm{~g}(95 \%)$. $-{ }^{1} \mathrm{H}$ NMR ([D 6 ]DMSO, $400 \mathrm{MHz}$, r. t., ppm): $\delta=2.86(\mathrm{~s}, 12 \mathrm{H}), 7.66(\mathrm{~m}, 12 \mathrm{H}), 7.80(\mathrm{~s}, 2 \mathrm{H}) .-{ }^{19} \mathrm{~F}$ NMR ([D 6$]$ DMSO, $377 \mathrm{MHz}$, r. t., ppm): $\delta=-60.02$ (s, 6F). $-{ }^{11} \mathrm{~B}$ NMR ([D 6 DMSO, $128 \mathrm{MHz}$, r. t., ppm): $\delta=-6.58$ (s). - IR $\left(\mathrm{cm}^{-1}\right): v=449(\mathrm{w}), 669(\mathrm{~m}), 709(\mathrm{~m}), 837(\mathrm{w}), 885$ (m), 1109 (vs), 1274 (vs), 1353 (s), 1415 (w), 1635 (m), 2210 (w), 2548 (vw). - Elemental analysis for $\mathrm{C}_{37} \mathrm{H}_{26} \mathrm{~N}_{3} \mathrm{BF}_{24}$ (\%): calcd. C 45.37, H 2.68, N 4.29; found C 45.20, H 2.72, $\mathrm{N} 4.35$.

Oxidation of sulfides to sulfoxides mediated by WCCWCA $\boldsymbol{6 b}$

Typical procedure for the oxidation of the sulfides in $\left[\mathrm{P}_{4,4,4,14}\right]\left[\mathrm{B}\left\{\mathrm{C}_{6} \mathrm{H}_{3}-3,5-\left(\mathrm{CF}_{3}\right)_{2}\right\}_{4}\right]$ : To a stirred solution of the sulfide $(2 \mathrm{mmol}, 0.24 \mathrm{~mL})$ in $\mathbf{6 b}(0.50 \mathrm{~mL})$, an aqueous solution of hydrogen peroxide $(30 \%$ in water) $(0.51 \mathrm{~mL}$, $5 \mathrm{mmol}$ ) was added in 2 to 3 portions at room temperature. The progress of the reaction was followed by TLC. The reaction mixture was extracted with $n$-hexane-diethyl ether $2: 1 \mathrm{v} / \mathrm{v}(5 \times 5 \mathrm{~mL})$, and the extract was dried over anhydrous $\mathrm{MgSO}_{4}$. The crude product was obtained by rolling evaporation and purified by column chromatography separation (silica gel using $n$-hexane-ethyl acetate 90:10 v/v). The yield and selectivity of methyl phenyl sulfoxide in kinetic and recycle experiments was calculated from calibration curves $\left(r^{2}>0.999\right)$ recorded using 3-methylanisole and 1,4-diacetylbenzene as internal standard. The WCCWCA was extracted with $\mathrm{CH}_{2} \mathrm{Cl}_{2}$ and then treated with $\mathrm{MnO}_{2}$ to destroy the excess peroxide. The obtained liquid was dried over anhydrous $\mathrm{MgSO}_{4}$ and then dried for $4 \mathrm{~h}$ in vacuo at $50^{\circ} \mathrm{C}$ to remove $\mathrm{CH}_{2} \mathrm{Cl}_{2}$. Fresh substrate and hydrogen peroxide were then added for a new reaction cycle. All products were characterized by melting point, ${ }^{1} \mathrm{H}$ NMR, ${ }^{13} \mathrm{C}$ NMR and IR spectroscopy (see the Supporting Information).

\section{Single-crystal $X$-ray structure determinations}

Data were collected on an X-ray single-crystal diffractometer equipped with a CCD detector (Bruker APEX II, $\kappa$ CCD), a rotating anode (Bruker AXS, FR591) with $\mathrm{MoK}_{\alpha}$ radiation $(\lambda=0.71073 \AA)$, and a graphite monochromator by using the SMART software package [105]. The measurements were performed on a single crystal coated with perfluorinated ether. The crystal was fixed on the top of a glass fiber and transferred to the diffractometer. The crystal was frozen in a stream of cold nitrogen. A matrix scan was used to deter- 
mine the initial lattice parameters. Reflections were merged and corrected for Lorenz and polarization effects, scan speed, and background using SAINT [73]. Absorption corrections, including odd and even ordered spherical harmonics were performed using SADABS [106]. Space group assignments were based upon systematic absences, $E$ statistics, and successful refinement of the structures. The structures were solved by Direct Methods with the aid of successive difference Fourier maps and were refined against all data using WINGX [107] based on SIR92 [108]. If not mentioned otherwise, non-hydrogen atoms were refined with anisotropic displacement parameters. Methyl hydrogen atoms were refined as part of rigid rotating groups, with $\mathrm{C}-\mathrm{H}=0.98 \AA$ and $U_{\text {iso }}(\mathrm{H})=1.5 \cdot U_{\text {eq }}(\mathrm{C})$. Other $\mathrm{H}$ atoms were placed in calculated positions and refined using a riding model, with methylene and aromatic $\mathrm{C}-\mathrm{H}$ distances of 0.99 and $0.95 \AA$, respectively, and $U_{\text {iso }}(\mathrm{H})=1.2 \cdot U_{\text {eq }}(\mathrm{C})$. Full-matrix least-squares refinements were carried out by minimizing $\Sigma w\left(F_{\mathrm{o}}^{2}-F_{\mathrm{c}}^{2}\right)^{2}$ with the SHELXL-97 weighting scheme [109]. Neutral atom scattering factors for all atoms and anomalous dispersion corrections for the non-hydrogen atoms were taken from International Tables for Crystallography [110]. Images of the crystal structures were generated by PLATON [111].

CCDC 956714 (2b), 956711 (5a), 956712 (6b), and 956713 (7a) contain the supplementary crystallographic data for this compound. These data can be obtained free of charge from The Cambridge Crystallographic Data Centre via www. ccdc.cam.ac.uk/data_request/cif.

\section{Single-crystal $X$-ray structure determination of compound $\mathbf{2 b}$}

Crystal data: empirical formula: $\mathrm{C}_{41} \mathrm{H}_{29} \mathrm{BF}_{24} \mathrm{~N}_{2}$; $M_{\mathrm{r}}=1016.47$; crystal color and shape: colorless block, crystal dimensions: $0.38 \times 0.51 \times 0.51 \mathrm{~mm}^{3}$; crystal system: monoclinic; space group: $P 22_{1} / c$ (no. 14); $a=20.1391(5)$, $b=13.9355(3), c=16.2559(4) \AA, \beta=111.2143(9)^{\circ}$, $V=4253.03(18) \AA^{3}, \quad Z=4, \quad \lambda\left(\mathrm{MoK}_{\alpha}\right)=0.71073 \AA$, $\mu=0.2 \mathrm{~mm}^{-1}, \quad \rho_{\text {calcd. }}=1.59 \mathrm{~g} \mathrm{~cm}^{-3}, \quad T=123(1) \mathrm{K}$, $F(000)=2040 e ; \theta$-range $=1.82-25.50^{\circ} ;$ data collected: 133524; independent data $\left[I_{\mathrm{O}}>2 \sigma\left(I_{\mathrm{O}}\right) /\right.$ all data / $\left.R_{\text {int }}\right]$ : 6806 / 7872 / 0.019; data/restraints / parameters: 7872 / $0 / 785 ; R_{1}\left[I_{\mathrm{o}}>2 \sigma\left(I_{\mathrm{o}}\right) /\right.$ all data $]: 0.0396 / 0.0472 ; w R 2$ $\left[I_{\mathrm{O}}>2 \sigma\left(I_{\mathrm{O}}\right) /\right.$ all data]: $0.0937 / 0.1006 ; \mathrm{GOF}=1.020$; $\Delta \rho_{\max / \min }: 0.47 /-0.43 e \AA^{-3}$.

\section{Single-crystal $X$-ray structure determination of} compound $5 \boldsymbol{a}$

Crystal data: empirical formula: $\mathrm{C}_{40} \mathrm{H}_{36} \mathrm{BF}_{20} \mathrm{P}$; $M_{\mathrm{r}}=938.47$; crystal color and shape: colorless fragment, crystal dimensions: $0.48 \times 0.56 \times 0.61 \mathrm{~mm}^{3}$; crystal system: orthorhombic; space group: $P c a 2_{1}$ (no. 29); $a=18.9591(7), \quad b=22.2987(8), \quad c=19.2449(7) \AA$, $V=8136.0(5) \AA^{3}, \quad Z=8, \quad \lambda\left(\mathrm{MoK}_{\alpha}\right)=0.71073 \AA$, $\mu=0.2 \mathrm{~mm}^{-1}, \quad \rho_{\text {calcd. }}=1.53 \mathrm{~g} \mathrm{~cm}^{-3}, T=123(1) \mathrm{K}$, $F(000)=3808 e ; \theta$-range $=0.91-25.40^{\circ} ;$ data collected: 231060; independent data $\left[I_{\mathrm{O}}>2 \sigma\left(I_{\mathrm{o}}\right) /\right.$ all data / $\left.R_{\mathrm{int}}\right]$ : 14524 / 14933 / 0.036; data/restraints / parameters: $14933 / 1 / 1126 ; R_{1}\left[I_{\mathrm{o}}>2 \sigma\left(I_{\mathrm{o}}\right) /\right.$ all data]: $0.0245 /$ $0.0257 ; w R 2\left[I_{\mathrm{o}}>2 \sigma\left(I_{\mathrm{o}}\right) /\right.$ all data]: $0.0667 / 0.0682$; $\mathrm{GOF}=1.046 ; \Delta \rho_{\max / \min }: 0.27 /-0.22 e \AA^{-3}$.

Single-crystal X-ray structure determination on compound bb

Crystal data: empirical formula: $\mathrm{C}_{58} \mathrm{H}_{68} \mathrm{BF}_{24} \mathrm{P}$; $M_{\mathrm{r}}=1262.90$; crystal color and shape: colorless fragment, crystal dimensions: $0.56 \times 0.59 \times 0.59 \mathrm{~mm}^{3}$; crystal system: triclinic; space group: $P \overline{1}$ (no. 2); $a=12.9732(4), \quad b=14.0401(4), \quad c=18.0389(5) \AA$, $\alpha=105.4144(14)^{\circ}, \beta=97.8526(13)^{\circ}, \gamma=97.5892(13)^{\circ}$, $V=3088.64(16) \AA^{3}, \quad Z=2, \quad \lambda\left(\mathrm{MoK}_{\alpha}\right)=0.71073 \AA$, $\mu=0.2 \mathrm{~mm}^{-1}, \quad \rho_{\text {calcd. }}=1.36 \mathrm{~g} \mathrm{~cm}^{-3}, \quad T=123(1) \quad \mathrm{K}$, $F(000)=1304 e ; \theta$-range $=1.19-25.43^{\circ} ;$ data collected: 95414; independent data $\left[I_{\mathrm{o}}>2 \sigma\left(\mathrm{I}_{\mathrm{o}}\right) /\right.$ all data $\left./ R_{\text {int }}\right]$ : 10444 / 11372 / 0.030; data/restraints / parameters: 11372 / $0 / 845 ; R_{1}\left[I_{\mathrm{O}}>2 \sigma\left(I_{\mathrm{o}}\right) /\right.$ all data $]: 0.0363$ / $0.0399 ; w R 2$ $\left[I_{\mathrm{O}}>2 \sigma\left(I_{\mathrm{O}}\right) /\right.$ all data]: $0.0889 / 0.0929 ; \mathrm{GOF}=1.015$; $\Delta \rho_{\max / \min }: 0.53 /-0.50 e \AA^{-3}$.

Single-crystal $X$-ray structure determination of compound $7 a$

Crystal data: empirical formula: $\mathrm{C}_{29} \mathrm{H}_{14} \mathrm{BF}_{20} \mathrm{~N}_{3}$; $M_{\mathrm{r}}=795.24$; crystal color and shape: colorless fragment, crystal dimensions: $0.10 \times 0.25 \times 0.36 \mathrm{~mm}^{3}$; crystal system: triclinic; space group: $P \overline{1}$ (no. 2); $a=8.1571(2), \quad b=12.7109(4), \quad c=14.5597(4) \AA$, $\alpha=89.4091(12)^{\circ}, \beta=83.9006(12)^{\circ}, \gamma=81.7908(12)^{\circ}$, $V=1485.66(7) \AA^{3}, \quad Z=2, \quad \lambda\left(\mathrm{MoK}_{\alpha}\right)=0.71073 \AA$ $\mu=0.2 \mathrm{~mm}^{-1}, \quad \rho_{\text {calcd. }}=1.78 \mathrm{~g} \mathrm{~cm}^{-3}, \quad T=123(1) \mathrm{K}$, $F(000)=788 e ; \quad \theta$-range $=1.41-25.43^{\circ} ;$ data collected: 51233; independent data $\left[I_{\mathrm{o}}>2 \sigma\left(I_{\mathrm{O}}\right) /\right.$ all data / $\left.R_{\mathrm{int}}\right]$ : 5014 / 5423 / 0.039; data/restraints / parameters: 5423 / $0 / 534 ; R_{1}\left[I_{\mathrm{o}}>2 \sigma\left(I_{\mathrm{o}}\right) /\right.$ all data]: $0.0296 / 0.0322 ; w R 2$ [ $I_{\mathrm{O}}>2 \sigma\left(I_{\mathrm{O}}\right) /$ all data]: $0.0778 / 0.0808 ; \mathrm{GOF}=1.031$; $\Delta \rho_{\max / \min }: 0.29 /-0.19 e \AA^{-3}$.

\section{Supporting information}

Detailed information on all crystal structure determinations, spectroscopic data, and characterization of all sulfoxides are given as Supporting Information (17 pages) available online (DOI: 10.5560/ZNB.2014-4165). 


\section{Acknowledgement}

B. Z. and. S. L. thank the TUM Graduate School for financial support. S.-L.Z. thanks the National Science
Foundation of China (21071073) and the Cooperation Project (21111130584) for financial support.
[1] T. Welton, Chem. Rev. 1999, 99, 2071-2083.

[2] T. Welton, Coord. Chem. Rev. 2004, 248, 24592477.

[3] J. P. Hallett, T. Welton, Chem. Rev. 2011, 111, $3508-3576$.

[4] P. Wasserscheid, W. Keim, Angew. Chem. Int. Ed. 2000, 39, 3772-3789.

[5] R. Sheldon, Chem. Commun. 2001, 2399-2407.

[6] J. Dupont, R. F. de Souza, P. A. Z. Suarez, Chem. Rev. 2002, 102, 3667-3692.

[7] N. V. Plechkova, K. R. Seddon, Chem. Soc. Rev. 2008, $37,123-150$.

[8] R. Noyori, M. Aoki, K. Sato, Chem. Commun. 2003, $1977-1986$.

[9] V. I. Pârvulescu, C. Hardacre, Chem. Rev. 2007, 107, $2615-2665$.

[10] T. L. Greaves, C. J. Drummond, Chem. Rev. 2008, 108, 206-237.

[11] M. A. P. Martins, C. P. Frizzo, D. N. Moreira, N. Zanatta, H. G. Bonacorso, Chem. Rev. 2007, 107, $2592-2614$.

[12] R. Giernoth, Angew. Chem. Int. Ed. 2010, 49, $2834-2849$.

[13] S. G. Lee, Chem. Commun. 2006, 1049-1063.

[14] J. T. Tindale, K. D. Hartlen, A. Alizadeh, M. S. Workentin, P. J. Ragogna, Chem. Eur. J. 2010, 16, $9068-9075$.

[15] A. Ouadi, B. Gadenne, P. Hesemann, J. J. E. Moreau, I. Billard, C. Gaillard, S. Mekki, G. Moutiers, Chem. Eur. J. 2006, 12, 3704-3081.

[16] T. Inagaki, T. Mochida, M. Takahashi, C. Kanadan, T. Saito, D. Kawahara, Chem. Eur. J. 2012, 18, 6795-6804.

[17] Z. R. Fei, T. J. Geldbach, D. B. Zhao, P. J. Dyson, Chem. Eur. J. 2006, 8, 156-160.

[18] D. Betz, P. Altmann, M. Cokoja, W. A. Herrmann, F. E. Kühn, Coord. Chem. Rev. 2011, 255, $1518-1540$.

[19] L. Graser, D. Betz, M. Cokoja, F. E. Kühn, Curr. Inorg. Chem. 2011, 1, 166-181.

[20] I. Krossing, J. M. Slattery, C. Daguenet, P. J. Dyson, A. Oleinikova, H. Weingärtner, J. Am. Chem. Soc. 2006, 128, 13427-13434.

[21] P. Hapiot, C. Lagrost, Chem. Rev. 2008, 108, $2238-2264$.

[22] I. J. B. Lin, C. S. Vasam, J. Organomet. Chem. 2005, 690, 3498-3512.
[23] Q. Zhang, S. Zhang, Y. Deng, Green Chem. 2011, 13, 2619-2637.

[24] U. Preiss, J. M. Slattery, I. Krossing, Ind. Eng. Chem. Res. 2009, 48, 2290-2296.

[25] J. M. Slattery, C. Daguenet, P. J. Dyson, T. J. S. Schubert, I. Krossing, Angew. Chem. Int. Ed. 2007, 46, $5384-5388$.

[26] I. Krossing, I. Raabe, Angew. Chem. Int. Ed. 2004, 43, $2066-2090$.

[27] K. Dong, S. Zhang, Chem. Eur. J. 2012, 18, $2748-2761$.

[28] A. R. Choudhury, N. Winterton, A. Steiner, A. I. Cooper, K. A. Johnson, J. Am. Chem. Soc. 2005, 127, $16792-16793$.

[29] A. R. Choudhury, T. N. G. Row, CrystEngComm 2006, $8,265-274$.

[30] W. M. Reichert, J. D. Holbery, R. P. Swatloski, K. E. Gutowski, A. E. Visser, M. Nieuwenhuyzen, K. R. Seddon, R. D. Rogers, Cryst. Growth Des. 2007, 7, $1106-1114$.

[31] J. D. Holbrey, W. M. Reichert, R. D. Rogers, Dalton Trans. 2004, 2267-2271.

[32] K. Fumino, A. Wulf, R. Ludwig, Angew. Chem. Int. Ed. 2008, 47, 3830-3834.

[33] R. P. Swatloski, J. D. Holbrey, R. D. Rogers, Green Chem. 2003, 5, 361-363.

[34] C. Roth, T. Peppel. K. Fumino, M. Köckerling, R. Ludwig, Angew. Chem. Int. Ed. 2010, 49, $10221-10224$.

[35] S. H. Strauss, Chem. Rev. 1993, 93, 927-942.

[36] C. A. Reed, Acc. Chem. Res. 1998, 31, 133-139.

[37] A. Bösmann, G. Francio, E. Janssen, W. Leitner, P. Wasserscheid, Angew. Chem. Int. Ed. 2001, 40, 2697-2699.

[38] A. Reisinger, I. Krossing, Coord. Chem. Rev. 2006, $250,2721-2744$.

[39] I. Raabe, K. Wagner, K. Guttsche, M. Wang, M. Grätzel, G. S. Quiñones, I. Krossing, Chem. Eur. J. 2009, 15, 1966-1976.

[40] T. Timofte, S. Pitula, A. V. Mudring, Inorg. Chem. 2007, 46, $10938-10940$.

[41] Z. B. Zhou, H. Matsumoto, K. Tatsumi, Chem. Eur. J. 2004, 10, 6581-6591.

[42] Z. B. Zhou, H. Matsumoto, K. Tatsumi, Chem. Eur. J. 2005, 11, 752-766.

[43] H. Matsumoto, Z. B. Zhou, H. Sakaebe, K. Tatsami, Electrochemistry 2005, 73, 633-635. 
[44] Z. B. Zhou, H. Matsumoto, K. Tatsumi, ChemPhys Chem 2005, 6, 1324-1332.

[45] A. S. Larsen, J. D. Holbrey, F. S. Tham, C. A. Reed, J. Am. Chem. Soc. 2000, 122, 7264-7272.

[46] J. Dymon, R. Wibby, J. Kleingardner, J. M. Tanski, I. A. Guzei, J. D. Holbrey, A. S. Larsen, Dalton Trans. 2008, 2999-3006.

[47] M. Bürchner, A. M. T. Erle, H. Scherer, I. Krossing, Chem. Eur. J. 2012, 18, 2254-2262.

[48] A. R. Katritzkhy, S. Singh, K. Kirichenko, M. Smiglak, J. D. Holbrey, W. M. Reichert, S. K. Spear, R. D. Rogers, Chem. Eur. J. 2006, 12, 4630-4641.

[49] M. Smiglak, C. C. Hines, T. B. Wilson, S. Singh, A. S. Vincek, K. Kirichenko, A. R. Katritzky, R. D. Rogers, Chem. Eur. J. 2011, 16, 1572-1584.

[50] M. Finze, E. Bernhardt, H. Willner, Angew. Chem. Int. Ed. 2007, 46, 9180-9196.

[51] P. Jutzi, C. Müller, A. Stammler, H.-G. Stammler, Organometallics 2000, 19, $1442-1444$.

[52] C. A. Reed, Acc. Chem. Res. 1998, 31, 325-332.

[53] R. E. LaPointe, G. P. Roof, K. A. Abbound, J. Klosin, J. Am. Chem. Soc. 2000, 122, $9560-9561$.

[54] S. J. Lancaster, D. A. Walker, M. Thornton-Pett, M. Bochmann, Chem. Commun. 1999, 1533 - 1534.

[55] E. Y.-X. Chen, T. J. Marks, Chem. Rev. 2000, 100, $1391-1434$.

[56] S. D. Ittel, L. K. Johnson, M. Brookhart, Chem. Rev. 2000, 100, 1169-1203.

[57] S. F. Rach, F. E. Kühn, Chem. Rev. 2009, 109, $2061-2080$.

[58] Y. Li, M. Cokoja, F. E. Kühn, Coord. Chem. Rev. 2011, 255, 1541- 1557.

[59] I. I. E. Markovits, W. A. Eger, S. Yue, M. Cokoja, C. J. Münchmeyer, B. Zhang, M.-D. Zhou, A. Genest, J. Mink, S.-L. Zang, N. Rösch, F. E. Kühn, Chem. Eur. J. 2013, 19, $5972-5979$.

[60] B. Zhang, S. Li, S. Yue, M. Cokoja, M.-D. Zhou, S.L. Zang, F. E. Kühn, J. Organomet. Chem. 2013, 744, $108-112$.

[61] B. Zhang, S. Li, A. Pöthig, M. Cokoja, S.-L. Zang, W. A. Herrmann, F. E. Kühn, Z. Naturforsch. 2013, $68 b, 587-597$.

[62] L. R. Graser, S. Jürgens, M. E. Wilhelm, M. Cokoja, W. A. Herrmann, F. E. Kühn, Z. Naturforsch. 2013, $68 b, 1138-1142$.

[63] B. Zhang, M. Köberl, A. Pöthig, M. Cokoja, W. A. Herrmann, F. E. Kühn, Z. Naturforsch. 2012, 67b, $1030-1036$.

[64] B. Zhang, M.-D. Zhou, M. Cokoja, J. Mink, S. L. Zang, F. E. Kühn, RSC Advances 2012, 2, $8416-8420$.

[65] S. A. Dharaskar, Res. J. Chem. Sci. 2012, 2, 80-85.

[66] I. V. Babich, J. A. Moulijn, Fuel 2003, 82, 607-631.
[67] K. Kaczorowska, Z. Kolarska, K. Mitka, P. Kowalski, Tetrahedron 2005, 61, 8315-8327.

[68] F. Brebion, B. Delouvrie, F. Najera, L. Fensterbank, M. Malacria, J. Vaissermann, Angew. Chem. Int. Ed. 2003, 42, $5342-5345$.

[69] M. S. Chen, M. C. White, J. Am. Chem. Soc. 2004, 126, 1346- 1347.

[70] E. Martin, D. L. Hughes, S. J. Lancaster, Inorg. Chim. Acta 2010, 363, 275-278.

[71] Y. Zhang, A. M. Santos, E. Herdtweck, J. Mink, F. E. Kühn, New J. Chem. 2005, 29, 366-370.

[72] A. R. Katritzky, S. Singh, K. Kirichenko, M. Smiglak, J. D. Holberey, W. M. Reichert, S. K. Spear, R. D. Rogers, Chem. Eur. J. 2006, 12, 4630-4641.

[73] J. Dymon, R. Wibby, J. Kleingardner, J. M. Tanski, I. A. Guzer, J. D. Holbrey, A. S. Larsen, Dalton Trans. 2008, 2999-3006.

[74] T. Peppel, C. Roth, K. Fumino, D. Paschek, M. Möckerling, R. Ludwig, Angew. Chem. Int. Ed. 2011, 50, $6661-6663$.

[75] K. Fumino, A. Wulf, R. Ludwig, Angew. Chem. Int. Ed. 2009, 48, 3184-3186.

[76] A. Wulf, K. Fumino, R. Ludwig, Angew. Chem. Int. Ed. 2010, 49, 449-453.

[77] B. E. Diebl, Y. Li, M. Cokoja, F. E. Kühn, N. Radhakrishnan, S. Zschoche, H. Komber, H. Y. Yeong, B. Voit, O. Nuyken, P. Hanefeld, H.-M. Walter, J. Polym. Sci., Part A: Polym. Chem. 2010, 48, 3775-3786.

[78] Y. Li, L. T. Voon, H. Y. Yeong, A. K. Hijazi, N. Radhakrishnan, K. Köhler, B. Voit, O, Nuyken, F. E. Kühn, Chem. Eur. J. 2008, 14, 7997-8003.

[79] A. K. Hijazi, N. Radhakrishnan, K. R. Jain, E. Herdtweck, O. Nuyken, H. M. Walter, P. Hanefeld, B. Voit, F. E. Kühn, Angew. Chem. Int. Ed. 2007, 46, $7290-7292$.

[80] F. Schödel, H. W. Lerner, M. B. Roig, M. Bolte, Acta Crystallogr. 2006, E62, 372-373.

[81] D. Brage, F. Grepioni, G. R. Desiraju, Chem. Rev. 1998, 98, $1375-1405$.

[82] F. A. Cotton, K. J. Wiesinger, Inorg. Chem. 1991, 30, $871-873$

[83] P. G. Jones, O. Crespo, Acta Crystallogr., Sect. C: Cryst. Struct. Commun. 1998, 54, 18-20.

[84] N. Kuhn, M. Walker, M. Steimann, Z. Naturforsch. 2002, 57b, 248-250.

[85] M. Köberl, M. Cokoja, B. Bechlars, E. Herdtweck, F. E. Kühn, Dalton Trans. 2011, 40, 11490-11496.

[86] K. Kaczorowska, Z. Kolarska, K. Mitka, P. Kowalski, Tetrahedron 2005, 61, 8315-8327.

[87] J. Drabowicz, M. Mikolajczyk, Synth. Commun. 1981, $11,1025-1030$.

[88] W. L. Xu, Y. Z. Li, Q. S. Zhang, H. S. Zhu, Synthesis 2004, $227-232$. 
[89] V. Hulea, P. Mordau, F. D. Renzo, J. Mol. Catal. A: Chem. 1996, 111, 325-332.

[90] K. S. Ravikumar, F. Barbier, J. P. Bégué, D. B. Delpon, J. Fluorine Chem. 1999, 95, $123-125$.

[91] J. Dupont, R. F. de Souza, P. A. Z. Suarez, Chem. Rev. 2002, 102, 3667-3692.

[92] J. W. Wiench, C. Michon, A. Ellern, P. Hazendonk, A. Luga, R. J. Angelici, M. Pruski, J. Am. Soc. Chem. 2009, 131, 11801-11810.

[93] C. Wamser, J. Am. Soc. Chem. 1951, 73, 409-416.

[94] I. Bányai, V. Conte, L. Pettersson, A. Silvagni, Eur. J. Inorg. Chem. 2008, 5373-5381.

[95] K. Kwon, J. Park, C. K. Lee, H. Kim, Int. J. Electrochem. Sci. 2012, 7, $9835-9843$.

[96] Y. S. Li, R. A. Larsen, F. O. Cox, J. R. Durig, J. Raman Spectrosc. 1989, 20, $1-9$.

[97] J. Mihály, S. Sterkel, H. M. Ortner, L. Kocsis, L. Hajba, É. Furdyga, J. Mink, Croat. Chem. Acta 2006, 79, $497-501$.

[98] S. Eltayeb, G. A. Guirgis, A. R. Fanning, J. R. Durig, J. Raman Spectrosc. 1996, 27, 111-126.

[99] J. Murto, A. Kivinen, K. Kajander, J. Hyömäki, J. K. Tommola, Acta Chem. Scand. 1973, 27, 96-106.

[100] B. C. Matusewicz, S. Pilorz, D. Bieńko, D. Michalska, Vib. Spectrosc. 2008, 47, 44-52.

[101] J. F. Kang, A. Ulman, R. Jordan, Langmuir 1999, 15, $5555-5559$.
[102] U. Lappan, U. Geißler, U. Scheler, K. Lunkwitz, Radiat. Phys. Chem. 2003, 67, 447-451.

[103] W. Grochala, M. K. Cytańskl, M. Derzsl, T. Michalowkl, P. J. Malinowski, Z. Mazej, D. Kurzydlowski, W. Koźmiński, A. Budzianowski, P. J. Leszyński, Dalton Trans. 2012, 41, 2034-2047.

[104] N. P. G. Roeges, A guide to the complex interpretation of infrared spectra of organic structures, John Wiley \& Sons, Chichester, 1994, 29-40.

[105] APEX suite of crystallographic software, APEX 2 (version 2008.4), Bruker Analytical X-ray Instruments Inc., Madison, Wisconsin (USA) 2008.

[106] SAINT (version 7.56a), SADABS (version 2008/1). Bruker Analytical X-ray Instruments Inc., Madison, Wisconsin (USA) 2008.

[107] L. J. Farrugia, J. Appl. Crystallogr. 1999, 32, $837-$ 838.

[108] A. Altomare, G. Cascarano, C. Giacovazzo, A. Gugliardi, M. C. Burla, G. Polidori, M. Camalli, J. Appl. Crystallogr. 1994, 27, 435.

[109] G. M. Sheldrick, Acta Crystallogr. 2008, A64, $112-122$.

[110] A. J. C. Wilson (Ed.), International Tables for Crystallography, Vol. C, Kluwer Academic Publishers, Dordrecht, 1992, Tables 6.1.1.4 (pp. 500-502), 4.2.6.8 (pp. 219-222), and 4.2.4.2 (pp. 193-199).

[111] A. L. Spek, Acta Crystallogr. 2009, D65, 148-155. 